\title{
Identification of remagnetization processes in Paleozoic sedimentary rocks of the northeast Rhenish Massif in Germany by K-Ar dating and REE tracing of authigenic illite and Fe oxides
}

\author{
A. Zwing, ${ }^{1,2}$ N. Clauer, ${ }^{3}$ N. Liewig, ${ }^{4}$ and V. Bachtadse ${ }^{1}$ \\ Received 4 October 2008; revised 11 February 2009; accepted 26 February 2009; published 13 June 2009.
}

[1] This study combines mineralogical, chemical (rare earth elemental (REE)) and isotopic (K-Ar) data of clay minerals as well as chemical compositions (major and REE) of Fe oxide leachates from remagnetized Palaeozoic sedimentary rocks from NE Rhenish Massif in Germany, for which the causes of remagnetization are not yet clear. The dominant carrier of the syntectonic, pervasive Carboniferous magnetization is magnetite. The Middle Devonian clastic rocks record an illitization event at $348 \pm 7$ Ma probably connected to a major magmatic event in the Mid-German Crystalline Rise, whereas a second illitization episode at $324 \pm 3 \mathrm{Ma}$ is coeval to the northward migrating deformation through the Rhenish Massif, being only detected in Upper Devonian and Lower Carboniferous rocks. The age of that younger illitization is not significantly different from that of the remagnetization, which, however, is not restricted to the upper part of the orogenic belt, but affects also the Middle Devonian strata. The REE patterns of the Fe-enriched leachates support two mineralization episodes with varied oxidation-reduction conditions outlined by varied $\mathrm{Eu}$ and $\mathrm{Ce}$ anomalies. This is not compatible with a unique, pervasive migration of orogenic fluids on a regional scale to explain the remagnetization in the studied region. While clay diagenesis and remagnetization are time-equivalent in Upper Devonian and Lower Carboniferous rocks, they are not so in Middle Devonian rocks. Transformation of smectite into illite cannot, therefore, account for the growth of associated authigenic magnetite, which must have been triggered by a different process. Since remagnetization and deformation ages are similar, the mechanism could relate to local physical conditions such as pressure solution and changing pore fluid pressure due to tectonic stress as well as to chemical conditions such as changing composition of the pore fluids.

Citation: Zwing, A., N. Clauer, N. Liewig, and V. Bachtadse (2009), Identification of remagnetization processes in Paleozoic sedimentary rocks of the northeast Rhenish Massif in Germany by K-Ar dating and REE tracing of authigenic illite and Fe oxides, J. Geophys. Res., 114, B06104, doi:10.1029/2008JB006137.

\section{Introduction}

[2] Understanding of the processes by which rocks become magnetized is most important for studies of ancient magnetization processes, regardless of their application to plate tectonic modeling, stratigraphic application, or unraveling mechanisms that control the Earth's magnetic field. Such processes are reasonably well known for primary magnetization recorded during rock formation, but they are often partly or completely erased by secondary magnetic overprints acquired any time after rock formation, which impacts are still poorly understood [Elmore et al., 2001; Stamatakos et al., 1996].

\footnotetext{
${ }^{1}$ Department of Earth and Environmental Sciences, Ludwig-Maximilians-Universität, Munich, Germany.

${ }^{2}$ Now at Ludwig-Maximilians-Universität, Munich, Germany.

${ }^{3}$ Centre de Géochimie de la Surface, Université Louis Pasteur, CNRS, Strasbourg, France.

${ }^{4}$ Département Ecologie, Physiologie et Ethologie, Institut Pluridisciplinaire Hubert Curien, Université Louis Pasteur, CNRS, Strasbourg, France.

Copyright 2009 by the American Geophysical Union. 0148-0227/09/2008JB006137\$09.00
}

[3] It is interesting to recall that secondary magnetic overprints are observed in almost all rock types, including the major sedimentary, magmatic and metamorphic lithologies. While rocks of all ages appear to have been subjected to remagnetization events, the Proterozoic and Paleozoic lithologies are affected even more often than the younger ones. The main handicap in the interpretation of such secondary magnetic overprints is the uncertainty associated with their timing and duration, as timing, for instance, is most often only estimated by comparing the magnetic directions to existing paleomagnetic data of the same units. Beside the large uncertainties associated with those age estimates, the age distribution of the magnetic overprints reveals that most remagnetization events in Paleozoic rocks occurred between 350 and $250 \mathrm{Ma}$, including the climax of the Variscan orogeny. This age span coincides with the Permo-Carboniferous Reversed Geomagnetic Superchron (PCRS), which is a long period of reverse polarity of the Earth magnetic field, approximately spanning from Namurian to Late Permian [Opdyke and Channell, 1996]. Both, the long period of reverse polarity during the PCRS and the 
Variscan orogeny are only two among many factors that are thought to have caused Late Paleozoic remagnetization [e.g., Stamatakos et al., 1996].

[4] Since the 1980 s, many detailed studies were undertaken on remagnetized rocks to better understand the inducing processes. Two types were mostly reported: (1) physical processes during which magnetization of existing minerals is reset by temperature [e.g., Dunlop and Özdemir, 1997; Kent, 1985], its direction changing by either a rotational deformation [Kodama, 1988], or a new magnetization imprinted by a differential stress [e.g., Borradaile, 1994; Hudson et al., 1989; Robion and Borradaile, 2001], and (2) chemical processes favoring the growth of new magnetic minerals or the dissolution of existing magnetic grains [Hirt et al., 1993]. In many published studies, links between remagnetization and regional fluid flows, hydrocarbon or clay diagenesis were suggested [e.g., Brothers et al., 1996; Elmore et al., 2001; Jackson et al., 1988; Lu et al., 1990, 1991; McCabe and Channell, 1994; McCabe et al., 1983; Oliver, 1986; Suk et al., 1990, 1993; Sun and Jackson, 1994; Xu et al., 1994]. Even knowing that formation of authigenic mica-type sheet silicates is common during fluid-triggered hydrothermal alteration or burial diagenesis [Gill et al., 2002; Katz et al., 2000; Woods et al., 2002], and although the isotopic and geochemical signatures of clay minerals can potentially constrain the timing of, and conditions during such events (see, for example, the review by Clauer and Chaudhuri [1995]), systematic investigations of clay minerals in remagnetized sedimentary rocks remain scarce [Elliott et al., 2006; Tohver et al., 2008]. Furthermore, despite tests of correlative chemical remagnetization and clay authigenesis, no direct evidence for cogenetic growth of magnetic minerals and mica-type sheet silicates has yet been reported, to the best of our knowledge.

[5] The main goal of the present work is therefore a contribution to a better understanding of diagenetic processes occurring during remagnetization events, by generating isotopic and geochemical determinations of authigenic minerals that formed during such events. The NE Rhenish Massif was chosen as the geologic area, because Late Paleozoic remagnetization overprinting the primary magnetic information and occurring during very low-grade metamorphic conditions was reported by Bachtadse et al. [1983], Wilken [1995] and Zwing et al. [2002]. In addition, its geodynamic evolution and deformation history is well known [Ahrendt et al., 1983; Franke, 2000; Oncken et al., 1999; Plesch and Oncken, 1999], while the origin and the reported remagnetization mechanisms are still unclear. Clay minerals from different types of remagnetized rocks previously studied by Zwing et al. [2002] for their magnetic properties, were separated and characterized for their mineralogical, geochemical and isotopic (K-Ar) signatures. For comparison of the geochemical signatures of authigenic clay and magnetic minerals, Fe oxides were leached from clay fractions and analyzed for their major and rare earth elemental (REE) contents.

\section{Geological Setting and Tectonic Evolution}

[6] The eastern Rhenish Massif is part of the Rhenohercynian fold belt, forming the northernmost tectonic-stratigraphic unit of the Central European Variscides as defined by Kossmat [1927]. In more recent plate tectonic concepts, the Rhenohercynian belt is designated as the foreland belt thrusted onto the southern margin of the Avalonian microcontinent during the Variscan orogeny [Franke, 2000, and references therein]. The sedimentary basin of the Rhenish Massif evolved from shallow marine and deltaic conditions on the southern shelf of the Old Red Continent during Early Devonian. Thick clastic deposits as well as red beds, root horizons and conglomerates characterize the Lower and Middle Devonian strata. During subsidence of the shelf, neritic facies gave way to hemipelagic and pelagic environments with localized growth of biohermal structures. Clastic sedimentation was almost completely terminated by a transgressive event at the Devonian-Carboniferous boundary, which led to the formation of a carbonate platform further to the north. At the same time, the closure of the Rhenohercynian basin induced the formation of a flysch trough, which propagated northwestward during the Early Carboniferous [Franke, 2000; Walliser, 1981]. Southward subduction of the Rhenohercynian oceanic basin beneath the Mid-German Crystalline Rise and the final collision of the bordering continental blocks resulted in a 50\% shortening $(200 \mathrm{~km})$ of the Rhenohercynian zone [Oncken et al., 1999].

[7] The kinematic evolution of the Rhenohercynian fold belt has been studied by a variety of methods in the recent decades, including strain measurements, metamorphic petrology and geochronology. Isotopic ages of synkinematic phyllosilicates (white mica, illite) from eastern Rhenish Massif and outlining a northward propagation of the deformation front, were first published by Ahrendt et al. [1983]. In rock types with distinct cleavage, mica formation and recrystallization processes are related to peak deformation and cleavage formation [Reuter, 1985]. More recent data [e.g., Reuter, 1987; Reuter and Dallmeyer, 1989] show that deformation started at around $320 \mathrm{Ma}$ to the south and migrated northward until $300 \mathrm{Ma}$ [Plesch and Oncken, 1999].

[8] Conodont alteration indices (CAI; see Epstein et al. [1977]) from Devonian and Carboniferous carbonate rocks [Königshof, 1992] and vitrinite reflectance data $\left(\mathrm{R}_{\max } \%\right.$; see Paproth and Wolf [1973]) indicate a general increase in paleotemperatures from diagenetic and very low-grade conditions $\left(<100-150^{\circ} \mathrm{C}\right)$ northward to epizonal conditions southward $\left(>300-350^{\circ} \mathrm{C}\right)$. To the north, vitrinite reflectance is correlated with the stratigraphic layering and $\mathrm{R}_{\max }$ isolines are folded and offset across faults, indicating preservation of a thermal state related to maximum burial near the onset of deformation. In the southern Rhenish Massif, $\mathrm{R}_{\max }$ isolines are not folded and crosscut the stratigraphic units. The average vitrinite reflectance is relatively high there $\left(5-7 \% \mathrm{R}_{\max }\right)$, even in the youngest pretectonic sediments. Consequently, a major tectonic overburden induced synkinematic resetting of maximum paleotemperatures [Plesch and Oncken, 1999, and references therein] in the southern part of the Rhenish Massif.

\section{Late Carboniferous Remagnetization}

[9] A paleomagnetic study of Devonian and Early Carboniferous sedimentary rocks from NE Rhenish Massif outlines a Late Carboniferous remagnetization obtained by thermal demagnetization experiments up to $550^{\circ} \mathrm{C}$ 


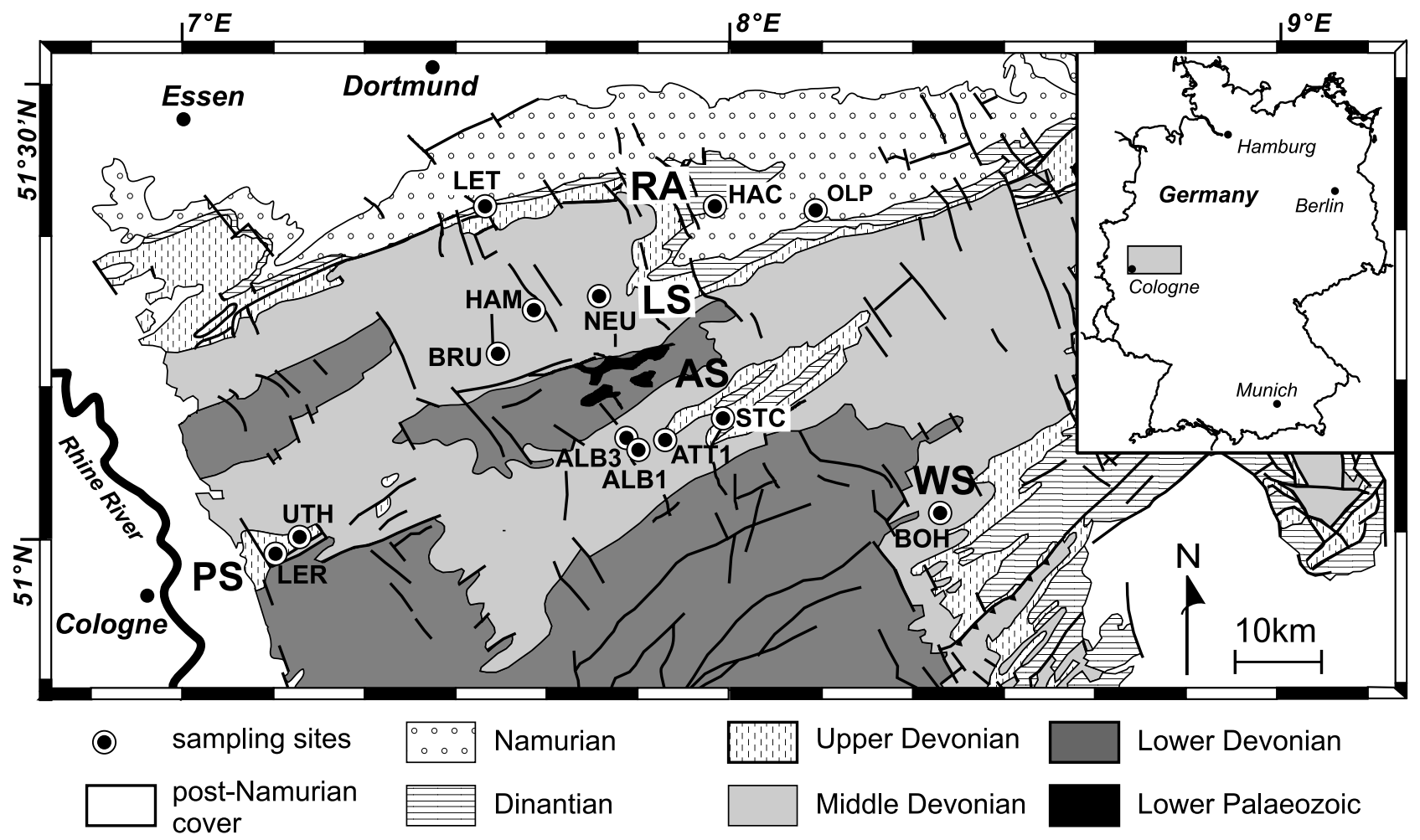

Figure 1. Geological sketch map of the NE Rhenish Massif with sampling locations. The main structural units where sampling was carried out include: Paffrath Syncline (PS), Remscheider Anticline (RA), Luedenscheider Syncline (LS), Attendorner Syncline (AS), and Wittgensteiner Syncline (WS). Site numbers refer to Table 1 .

(see component B in the work of Zwing et al. [2002]). Three individual incremental regional fold tests across the Remscheider Anticline (RA), Luedenscheider Syncline (LS), Attendorner Syncline (AS) and Wittgensteiner Syncline (WS in Figure 1) show a unique and distinctive variation in timing of remagnetization relative to the age of folding. Remagnetization occurred after folding to the south and was contemporaneous to folding to the north of the area. Timing and duration of the remagnetization event is therefore constrained by the age of folding, which varies throughout the area and reflects a northward migration of the deformation front from 315 to $300 \mathrm{Ma}$ [Ahrendt et al., 1983]. The concordance of the magnetic inclinations obtained from entire area indicates that the rocks were remagnetized during a relatively short time period of only a few millions of years. Magnetite was identified as the most important carrier of the late Paleozoic magnetization component. Ultrafine magnetite is present in the carbonate rocks as demonstrated by rock magnetic experiments [Zwing et al., 2005]. Occurrence of ultrafine grained magnetic material, together with the determination of low paleotemperatures [Königshof, 1992] and high unblocking temperatures for the remagnetization component [Zwing et $a l ., 2002]$ give strong evidence for a chemical remagnetization process during Late Carboniferous.

\section{Sampling and Analytical Procedure}

\subsection{Sampling}

[10] The majority of the samples selected for isotopic and geochemical determinations of authigenic minerals were taken at locations where paleomagnetic and rock magnetic studies had been carried out before (Figure 1). As in the paleomagnetic and rock magnetic studies [Zwing et al., 2002, 2005], sampling was restricted to the northern part of the Rhenish Massif, where paleotemperatures are below $300^{\circ} \mathrm{C}$ (CAI <4, Rmax <3.5\%; see Königshof [1992] and Paproth and Wolf [1973]). Exposures with macroscopic evidences for fracturing, internal deformation (foliation), or weathering were discarded. The hand samples or drill cores were taken directly adjacent to the paleomagnetic test locations; they are listed and described in Table 1.

[11] The sedimentary rocks of the Rhenish Massif can be subdivided in three major groups: (1) siliciclastic rocks deposited in neritic to pelagic environments; (2) carbonate rocks deposited on the Late Devonian/Early Carboniferous carbonate platform; and (3) carbonate rocks formed in the vicinity of bioherms. The majority of the samples studied was taken from siliciclastic rocks (ALB1, ALB3, ATT1, BRU, HAM, NEU, OLP), which is the most common lithology in the NE Rhenish Massif. The siliciclastic rocks consist mainly of quartzwackes and lithic greywackes containing significant amounts $(>15 \%)$ of silt-grade quartz and clay minerals. The occurrence of plant fragments and dark gray colors indicate anoxic to suboxic conditions during sedimentation and early diagenesis. The grain sizes of siliciclastic rocks typically fall in the range of fine-grained sandstones. The platform carbonate rocks (LET, HAC, LER, UTH) are commonly biomicrites and oomicrites [Folk, 1959], which can contain significant amounts of biogenic material. Samples UTH and LER were taken in 
Table 1. Location, Description, and Stratigraphic Age of the Selected Samples From NE Rhenish Massif

\begin{tabular}{lccllll}
\hline Sample & Latitude $\left({ }^{\circ} \mathrm{N}\right)$ & Longitude $\left({ }^{\circ} \mathrm{E}\right)$ & \multicolumn{1}{c}{ Location } & \multicolumn{1}{c}{ Lithology } & \multicolumn{1}{c}{ Stratigraphic Unit } & \multicolumn{1}{c}{ Stratigraphic Age } \\
\hline LET & 51.375 & 7.561 & Henkhausen, near public pool & cherty carbonate & Kieselkalk-Horizont & Tournaisian \\
HAC & 51.373 & 7.976 & old quarry at B229, west of Hachen & bituminous limest. & $\begin{array}{l}\text { Kulm-Plattenkalk } \\
\text { Sandstone }\end{array}$ & $\begin{array}{l}\text { Honseler Schichten } \\
\text { Visean }\end{array}$ \\
BRU & 51.209 & 7.578 & roadcut at B54, south of Brügge & savetian \\
HAM & 51.257 & 7.644 & old quarry at L530, opposite of factory & sandstone & Honseler Schichten & Givetian \\
NEU & 51.272 & 7.778 & old quarry near B229, south of Neuenrade & quartzitic sandstone & Honseler Schichten & Givetian \\
OLP & 51.366 & 8.164 & roadcut at A46, south of Olpe & greywacke & Arnsberger Schichten & Namurian \\
ALB1 & 51.106 & 7.823 & roadcut SW of Albringhausen & siltstone & Wiedenester Schichten & Givetian \\
ALB2 & 51.111 & 7.818 & roadcut at L539, west of Albringhausen & sandstone & Selscheider Schichten & Eifelian \\
ATT & 51.111 & 7.879 & roadcut at L708, south of Attendorn & gray/red sandstone & U. Newberrien Schichten & Givetian \\
STC & 51.137 & 7.986 & old quarry, east of Sankt Claas & limestone & Massenkalk & Frasnian \\
BOH & 51.024 & 8.387 & active quarry (Fa. Böhl) near Raumland & quartzitic sandst. & Raumländer Schichten & Eifelian \\
LER & 50.954 & 7.152 & old quarry in park, Hotel Lerbach & bituminous limest. & Hombacher Schichten & Frasnian \\
UTH & 51.010 & 7.196 & old quarry at L286 near Unterthal & limestone & Unterer Plattenkalk & Givetian \\
\hline
\end{tabular}

the Paffrath Syncline (PA), where the paleotemperatures were found to be minimal $\left(\mathrm{CAI}=1.5 ; \mathrm{R}_{\max }=0.9 \%\right)$. Limestones and dolomites (STC) from carbonate buildups (bioherms) are mainly authochtonous biolithites and dolomicrites [Folk, 1959]. All carbonate rocks are characterized by low amounts of clay minerals. At site $\mathrm{BOH}$, a green tuff turned out to be much more suitable for geochemical and isotopic studies than the adjacent quartzarenites that were sampled for paleomagnetic studies.

\subsection{Analytical Procedure}

[12] During preparation of the $<2 \mu$ m clay fractions, great care was taken to prevent contamination either by coarsegrained detrital minerals during crushing of the samples, or by anthropogenic magnetic material during dissolution of the Fe oxides. The samples were cleaned with distilled water, dried and crushed using a hydraulic press to produce $2-4 \mathrm{~cm}$ sized rock fragments. Gentle disaggregation of the fragments using repetitive freezing-thawing cycles was tested on four pilot samples (ALB1, ATT1, HAC, LET) for three months [Liewig et al., 1987]. However, owing to high cementation of the selected rocks, this disaggregation method was not very efficient. All samples were then carefully crushed in an agate mortar with a grinding pillar also in agate.

[13] The carbonates were dissolved using a buffered solution of $\mathrm{Na}$ acetate and acetic acid at a $\mathrm{pH}$ of about 4.5. The $<2 \mu \mathrm{m}$ fraction containing most of the clay material was extracted by sedimentation in distilled water according to Stokes' law. The $<0.2$ and $0.2-2 \mu \mathrm{m}$ fractions were separated from $<2 \mu \mathrm{m}$ fraction by ultra high-speed centrifugation following the procedure described by Larqué and Weber [1978]. The separated fractions were examined with a scanning- (SEM) and a transmission-electron microscope (TEM) to assess the clay mineral morphologies and grain size distributions.

[14] The $<0.2,0.2-2$ and $<2 \mu \mathrm{m}$ fractions were analyzed by X-ray diffractometry (XRD, Co $\mathrm{K} \alpha, 40 \mathrm{kV}$, Fe filter, $0.2-1^{\circ}$ slits). Smear specimens of the different size fractions were prepared on glass slides and analyzed four times for an accurate identification of the clay components: (1) dried at room conditions and called "untreated," (2) after $12 \mathrm{~h}$ in an ethylene-glycol atmosphere, (3) after $12 \mathrm{~h}$ in hydrazine atmosphere, and (4) after $4 \mathrm{~h}$ at $490^{\circ} \mathrm{C}$ [Moore and Reynolds, 1989]. The illite crystallinity was studied to evaluate the degree of the diagenetic to very low-grade metamorphic impact. For quantification, the illite crystallinity index (ICI) was used by measuring the full width at half maximum (FWHM) of the first illite basal reflection $(10 \AA)$ [Kübler, 1966]. The boundaries between nonmetamorphic/ anchizone and anchizone/epizone are defined at 0.58 and $0.35^{\circ} 2 \Theta$, respectively, for the $<2 \mu \mathrm{m}$ air-dried clay fractions at the analytical conditions used here [Larqué and Weber, 1978]. It shall be recalled that the values are strictly dependent on sample preparation and experimental setup, so that comparison of values obtained by different teams with different procedures should be cautious.

[15] The morphology, composition and distribution of the authigenic clay particles and their genetic association with authigenic ferromagnetic grains were investigated with secondary electrons under an SEM. Detection of very finegrained $\mathrm{Fe}$ oxides (magnetite, hematite) and $\mathrm{Fe}$ sulfides (pyrite, pyrrhotite) was obtained by imaging density-sensitive backscattered electrons.

[16] Major and rare earth elements (REEs) were determined on the $<0.2 \mu \mathrm{m}$ fractions of all samples. The preparation and analytical procedure is that of Samuel et al. [1985], the final solutions being analyzed by ICP-MS and ICP-AES, with an analytical uncertainty $( \pm 3 \%$ for the major and $\pm 10 \%$ for the REEs) controlled by periodic determinations of the BE-N (basalt; see Govindaraju and Roelandst [1993]) and GL-O (glauconite; see Govindaraju [1994]) geostandards. Potassium for the K-Ar age determinations was measured on an atomic-absorption spectrometer calibrated to internal $\mathrm{K}$ standard solutions; the reproducibility being better than $\pm 1.5 \%$. REE concentrations of the $<0.2 \mu \mathrm{m}$ fractions and leachates were normalized using the North American Shale Composites (NASC) of McLennan [1989] as a reference. The $\mathrm{Eu}$ and $\mathrm{Ce}$ anomalies were calculated by comparison with the means of the normalized values of the neighboring elements (labeled $\mathrm{Eu}^{*}, \mathrm{Ce}^{*}$; see Taylor and McLennan [1985]). The analytical error of the REE concentrations in the NASC was considered to be small relative to that of the investigated samples $( \pm 10 \%)$ and was neglected. Consequently, the maximum relative uncertainty for the $\mathrm{Ce} / \mathrm{Ce}^{*}$ and $\mathrm{Eu} / \mathrm{Eu}^{*}$ ratios is about $20 \%$ and samples with ratios between 0.8 and 1.2 were considered to have no anomalies.

[17] The K-Ar determinations were completed on the $<0.2 \mu \mathrm{m}$ fractions of all samples and the $<2 \mu \mathrm{m}$ fraction 
of the pilot samples, following a procedure close to that described by Bonhomme et al. [1975]. The samples were preheated to $80^{\circ} \mathrm{C}$ for several hours to reduce the amount of atmospheric $\mathrm{Ar}$ absorbed on the mineral surfaces during sample preparation and handling. The results were controlled by repetitive analysis of the GL-O standard averaging $24.67 \pm 0.18 \times 10^{-6} \mathrm{~cm}^{3} / \mathrm{g} \mathrm{STP}(2 \sigma)$ of radiogenic ${ }^{40} \mathrm{Ar}$ for 12 independent determinations during the course of the study. The atmospheric ${ }^{40} \mathrm{Ar} /{ }^{36} \mathrm{Ar}$ ratio was also measured periodically and averaged $300.8 \pm 7.9(2 \sigma)$. The K-Ar ages were calculated using Cox and Dalrymple's [1967] formula with the decay constants recommended by Steiger and Jäger [1977]. The errors during sample weighting, ${ }^{38} \mathrm{Ar} /{ }^{36} \mathrm{Ar}$ and ${ }^{40} \mathrm{Ar} /{ }^{38} \mathrm{Ar}$ measurements and $\mathrm{K}_{2} \mathrm{O}$ analysis were taken into account for calculation of the age uncertainties. K-Ar isochrons were calculated using the Isoplot software [Ludwig, 2001]. Whenever reasonable, York's [1969] algorithm was used for error estimation.

[18] The Fe oxides were leached from $<0.2 \mu \mathrm{m}$ fractions using dithionite $\left(\mathrm{Na}_{2} \mathrm{~S}_{2} \mathrm{O}_{4}\right)$ buffered to a $\mathrm{pH}$ of 7.3 , which is known to be very effective for dissolution of free Fe oxides, without extracting Fe from silicate crystal lattices [Mehra and Jackson, 1960]. This leaching was made, because $<0.2 \mu$ m clay fractions: (1) potentially contain magnetite and hematite grains that might carry ancient magnetizations, and (2) also can include potential superparamagnetic grains that characterize chemical remagnetization. About $100-$ $120 \mathrm{mg}$ of a size fraction were suspended in centrifugation tubes with $4 \mathrm{ml}$ of $0.3 \mathrm{M} \mathrm{Na}$ citrate and $0.5 \mathrm{ml} 1 \mathrm{M} \mathrm{NaHCO}_{3}$, and were heated to $80^{\circ} \mathrm{C}$. Then, $\sim 100 \mathrm{mg}$ of $\mathrm{Na}_{2} \mathrm{~S}_{2} \mathrm{O}_{4}$ were added and the tube shaken for $15 \mathrm{~min}$. After addition of $1 \mathrm{ml}$ saturated $\mathrm{NaCl}$, the suspension was centrifuged at $4000 \mathrm{rpm}$ and poured into PVC containers. The dried material was dissolved first in $4 \mathrm{ml} 10 \mathrm{~N} \mathrm{HCl}$ and $2 \mathrm{ml} 14 \mathrm{~N} \mathrm{HNO}_{3}$, and in $2 \mathrm{ml} 14 \mathrm{~N} \mathrm{HNO}_{3}$ after evaporation at $100^{\circ} \mathrm{C}$. The solution was diluted with bidistilled water in volumetric flasks and analyzed by ICP-AES and ICP-MS for the major (except $\mathrm{Na}$ and $\mathrm{K})$ and REE contents, respectively. Not available in highly purified quality, dithionite contains significant amounts of $\mathrm{Zn}, \mathrm{Cr}, \mathrm{Ni}, \mathrm{Cu}, \mathrm{Mo}$ and $\mathrm{Sr}(>0.5 \mathrm{ppm})$. Its contamination and that from the other reagents were, therefore, controlled by preparing a complete procedure without any sample powder, in analyzing the elemental contents. Owing to possible precipitation of $\mathrm{S}$ from solutions [Mehra and Jackson, 1960], estimation of the amount of leached material by weighting the residue being also a problem, the elemental contents of the leachates are given as oxides relative to the total amount of matter leached with dithionite; the results listed are blank-corrected.

\section{Results}

\subsection{Clay Mineralogy and Geochronology}

[19] No pervasive internal deformation could be detected in the rocks by transmitted light microscopy of polished thin sections, while primary sedimentary fabrics, such as bioturbation and imbrication of sheet silicates and shell fragments, were often found preserved. The bioclasts and ooliths of the carbonates are undeformed and recrystallized into sparitic calcite and dolomite. Pressure-solution features were also often observed along grain boundaries in the quartz-rich lithologies, the samples being generally charac- terized by high compaction and very low porosity. The intergranular pore spaces in the sandstones as well as the intraparticulate and vug porosities in the carbonates are filled with calcite and dolomite cements. Small volumes of free intergranular porosity were only observed in the greywackes.

[20] Two illite morphologies could be identified by SEM and TEM observation. Subeuhedral and irregular particles occur as overgrowth of detrital and authigenic minerals. In carbonates, illite coats large grains of authigenic kaolinite $(<10 \mu \mathrm{m})$ occurring in calcite veins (LET; see Figure $2 \mathrm{a}$ ). Overgrowth of subeuhedral illite was also observed on detrital muscovite particles of siltstones and sandstones. Lamellar to fibrous illite fills small intergranular pores of the greywackes (OLP; see Figure 2b). The separated clay fractions consist generally in irregular illite morphologies, idiomorphic hexagonal or elongated shapes being rare. The particle size distribution is highly inhomogeneous in the $<2 \mu \mathrm{m}$ fractions, and even the smallest grains show irregular morphologies (HAC; see Figure 2c). This supports either an illite growth hindered by highly constricted interstitial space or particle destruction during sample preparation by over-crushing. Interestingly, the irregular illite morphologies and inhomogeneous sizes are observed in both the clastic and carbonate lithologies. While overcrushing is a known hint in the study of clastic rocks, disaggregation of carbonates is mainly completed by acid dissolution, which cannot account for the observed particle morphologies. In addition, the clay particles released from washed rock fragments of sample HAM after short ultrasonic treatment show the same characteristics as the other $<2 \mu \mathrm{m}$ fractions (Figure 2d), strongly attesting against any significant effect of sample preparation on the morphology and size of the clay particles. Alternatively, it favors a very restricted interstitial volume during illite growth.

[21] The TEM observations also point to large amounts of clay particles with small sizes $<0.2 \mu \mathrm{m}$ in all studied lithologies. In addition, lack of significant contamination by detrital sources inclined us to consider that the $<0.2 \mu \mathrm{m}$ size fraction represents best the authigenic clay minerals, so that it was selected for $\mathrm{K}-\mathrm{Ar}$ age determinations and trace element geochemistry.

[22] The XRD determinations show that illite and chlorite are the dominant minerals of the $<0.2 \mu \mathrm{m}$ fractions. The presence of kaolinite in one sample (LET) is indicated by a reflection near $7 \AA$ that shifted, as expected, toward $10 \AA$ after hydrazine treatment. In many samples, weak reflections at 4.26 and $3.15-3.21 \AA$ indicate the presence of minute amounts of quartz and feldspars, respectively. Feldspar was mostly identified in the $0.2-2$ and $<2 \mu$ m fractions of some samples, while never observed in $<0.2 \mu \mathrm{m}$ fractions. The detailed mineralogy of the $<2 \mu \mathrm{m}, 0.2-2 \mu \mathrm{m}$ and $<0.2 \mu \mathrm{m}$ fractions is given in Table 2 . The XRD patterns of the $<0.2$ and $<2 \mu \mathrm{m}$ fractions are significantly different, depending on the lithology of the rocks. The $<2 \mu \mathrm{m}$ fractions from clastic rocks (e.g., ALB3; see Figure 3a) contain illite, chlorite and small amounts of quartz and albite. In the very fine $<0.2 \mu \mathrm{m}$ fractions, the relative intensities of the 10 and $14 \AA$ peaks indicate a higher amount of illite and a lower but still significant amount of chlorite $(\sim 25-40 \%)$. The intensity of the $14 \AA$ peak increases after heating to $490^{\circ} \mathrm{C}$, indicating the presence 

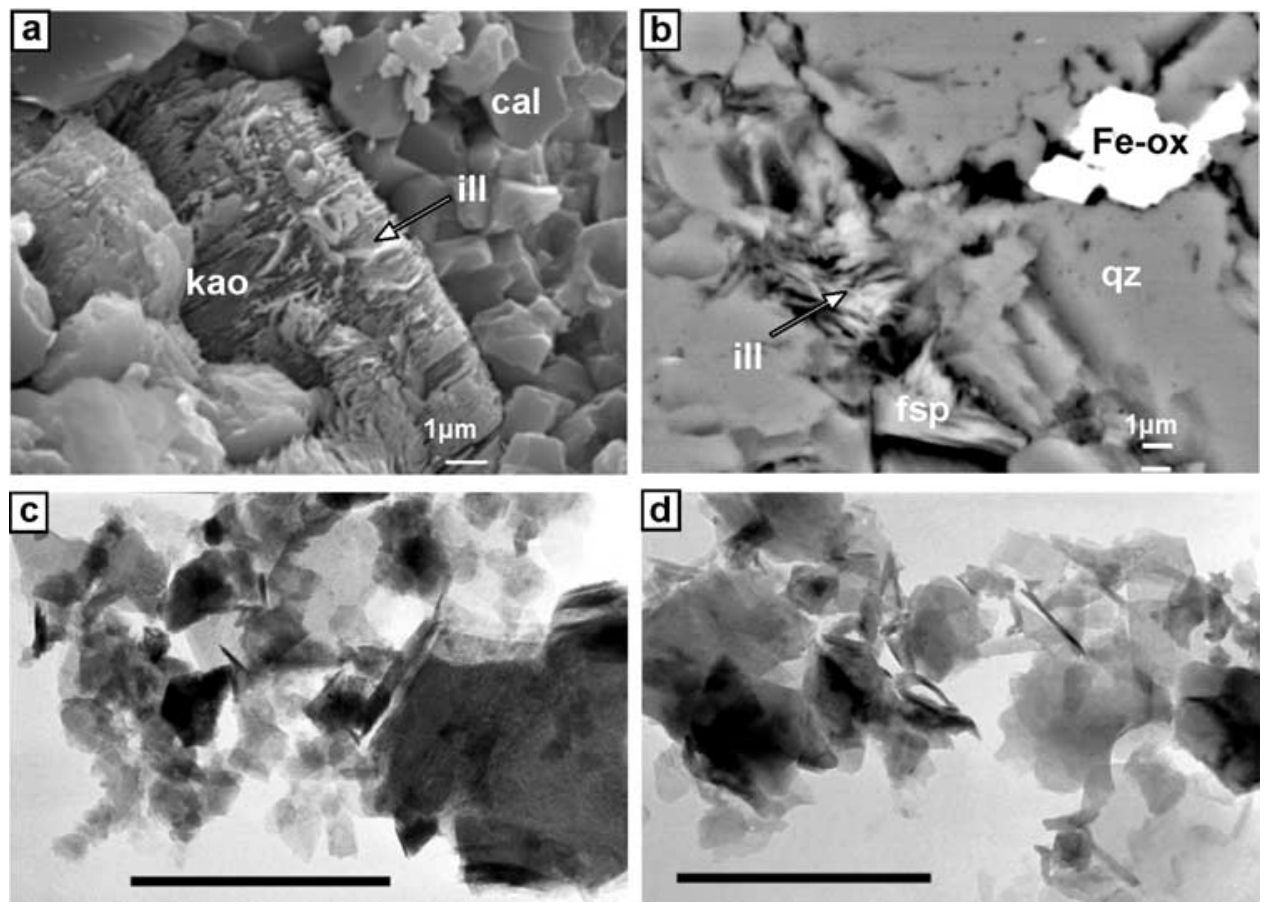

Figure 2. Scanning electron micrograph (SEM) and transmission electron micrograph (TEM). (a) SEM image of sample LET. Abbreviations are as follows: ill, illite; kao, kaolinite; cal, calcite. (b) Backscattered electron image of a polished section of sample OLP. Abbreviations are as follows: qz, quartz; fsp, feldspar; Fe-ox, Fe oxide (magnetite). (c) TEM image of the $<2 \mu \mathrm{m}$ fraction of sample HAC. (d) TEM image of fine-grained material released from sample HAM after a $1 \mathrm{mn}$ ultrasonic treatment. The bars in Figures $2 \mathrm{c}$ and $2 \mathrm{~d}$ are $1 \mu \mathrm{m}$ long.

of Fe-rich chlorites. Illite is predominant in the $<0.2$ and $<2$ $\mu \mathrm{m}$ fractions of the carbonate rocks, with minute amounts of chlorite and of other accessory minerals (e.g., STC; see Figure $3 b)$.

[23] The (001) illite reflection is generally asymmetric with a shoulder toward lower diffraction angles, and it moves slightly to lower diffraction angles after ethyleneglycol treatment. Both, the asymmetry and the peak shift characterize an illite-smectite interstratification that is more pronounced in the carbonates [Brindley and Brown, 1980]. However, the difference in width of the $10 \AA$ peak from untreated and ethylene-glycolated samples does not exceed $0.1^{\circ}(2 \Theta)$. In some samples, the $10 \AA$ peak is only slightly sharper after ethylene-glycol treatment (Table 2). The differences in the $10 \AA$ peak width of untreated and glycolated specimens from the same samples being not significant, only very limited amounts of smectite layers are expected.

[24] The ICI of the $0.2-2 \mu \mathrm{m}$ air-dried fractions ranges from 0.3 to $0.8^{\circ}(2 \Theta)$. It is highest in the carbonate samples from Remscheid Anticline and Paffrath Syncline at 0.7 to $0.8^{\circ}(2 \Theta)$ (locations RA and PS in Figure 1), and significantly lower in the clastic rocks from Lüdenscheid, Attendorn and Wittgenstein synclines at 0.3 to $0.45^{\circ}(2 \Theta)$ (locations LS and AS/WS in Figure 1). The clay fraction from $\mathrm{BOH}$ tuff layer has an unusually high ICI $\left(0.75^{\circ}(2 \Theta)\right)$ pointing to a larger occurrence of smectite layers in the illite-smectite mixed layer. The ICI of the $<0.2 \mu \mathrm{m}$ air-dried fractions is generally higher than that of the corresponding $<2 \mu \mathrm{m}$, with an ICI up to $1.0^{\circ}(2 \Theta)$ in sample LER, but it follows the same trend as that of the coarser fractions.
[25] The influence of different disaggregation methods on the apparent $\mathrm{K}-\mathrm{Ar}$ ages was studied on clay fractions of four pilot samples (LET, HAC, ALB1, ATT1). A set of $<2 \mu \mathrm{m}$ fractions called LETa, HACa, ALB1a, ATT1a, and of $<0.2 \mu \mathrm{m}$ fractions called LETb, HACb, ALB1b, ATT1b were extracted after gentle disaggregation of rock pieces using repetitive freezing-thawing cycles for three months and subsequent gentle crushing with the mortar grinder. Except for the HACa fraction, the $<2 \mu \mathrm{m}$ fractions yield systematically the highest apparent K-Ar ages (Table 3 ). The K-Ar apparent age of the $<2 \mu \mathrm{m}$ ALB1a fraction (388 \pm $9 \mathrm{Ma}$ ) is close to the age range of detrital muscovites from Rhenish Massif (409-459 Ma; Franke, 2000), clearly outlining contamination by detrital muscovite or $\mathrm{K}$ feldspar, which is confirmed by the XRD patterns. The apparent KAr ages of the $<0.2 \mu \mathrm{m}$ fractions are significantly lower than those of the corresponding $<2 \mu \mathrm{m}$ fractions, pointing to a lower influence of the detrital material. However, the samples from carbonates yield quite large uncertainties (LETb: $303 \pm 22 \mathrm{Ma}$; HACb: $340 \pm 17 \mathrm{Ma}$ ), owing to lower $\mathrm{K}$ contents and higher amounts of atmospheric $\mathrm{Ar}$ (Table 3). Owing to the large uncertainties, the K-Ar results of the two LETb and HACb clay fractions were discarded from further interpretation. A set of $<0.2 \mu \mathrm{m}$ fractions was also separated from pilot samples after gentle crushing with the mortar grinder and treatment with a buffered solution of acetic acid for removal of the carbonate minerals. These fractions called LET, HAC, ALB1 and ATT1 yield similar $\mathrm{K}-\mathrm{Ar}$ data, within analytical uncertainty, having smaller uncertainties than the first set of separates. These results 
Table 2. Mineral Composition of the Clay Fractions and ICI Data of the Air-Dried and Glycolated $<0.2,0.2-2$, and $<2 \mu \mathrm{m}$ Fractions ${ }^{\mathrm{a}}$

\begin{tabular}{|c|c|c|c|c|c|c|c|c|}
\hline \multirow[b]{2}{*}{ Sample } & \multirow[b]{2}{*}{ Ill } & \multirow[b]{2}{*}{$\mathrm{I} / \mathrm{S}$} & \multirow[b]{2}{*}{ Chl } & \multirow[b]{2}{*}{ Kao } & \multirow[b]{2}{*}{ Qz } & \multirow[b]{2}{*}{ Fsp } & \multicolumn{2}{|c|}{ FWHM $\left({ }^{\circ} 2 \theta \mathrm{Cu} \mathrm{K} \alpha\right)$} \\
\hline & & & & & & & Air Dried & Glycolated \\
\hline \multicolumn{9}{|c|}{ After Crushing and Treatment With Acetic Acid } \\
\hline LET $<0.2$ & 62 & 11 & 18 & 9 & & & 0.9 & 0.9 \\
\hline LET $0.2-2$ & 48 & 20 & 7 & 25 & $\mathrm{x}$ & & 0.8 & 0.8 \\
\hline $\mathrm{HAC}<0.2$ & 100 & $\varepsilon$ & & & $\varepsilon$ & & 0.8 & 0.9 \\
\hline HAC $0.2-2$ & 100 & $\varepsilon$ & & & $\mathrm{x}$ & & 0.85 & 0.9 \\
\hline BRU $<0.2$ & 65 & 9 & 26 & & $\mathrm{x}$ & $\mathrm{x}$ & 0.6 & 0.55 \\
\hline BRU $0.2-2$ & 52 & 5 & 43 & & $\mathrm{xx}$ & $\mathrm{x}$ & 0.4 & 0.35 \\
\hline HAM $<0.2$ & $\mathrm{xx}$ & & $\mathrm{x}$ & & & & 0.5 & 0.55 \\
\hline HAM $0.2-2$ & 75 & & 25 & & $\mathrm{x}$ & $\mathrm{x}$ & 0.45 & 0.4 \\
\hline HAM <2 & 70 & & 30 & & $\mathrm{x}$ & $\mathrm{x}$ & 0.4 & 0.35 \\
\hline NEU $<0.2$ & 63 & & 37 & & & & 0.45 & 0.45 \\
\hline NEU $0.2-2$ & 46 & & 54 & & $\mathrm{x}$ & $\mathrm{x}$ & 0.3 & 0.3 \\
\hline NEU <2 & 47 & & 53 & & $\mathrm{xx}$ & $\mathrm{xx}$ & 0.45 & 0.4 \\
\hline OLP $<0.2$ & 67 & & 33 & & & & 0.7 & 0.6 \\
\hline OLP $0.2-2$ & 50 & & 50 & & $\mathrm{x}$ & $\mathrm{x}$ & 0.45 & 0.45 \\
\hline $\mathrm{OLP}<2$ & 47 & & 53 & & $\mathrm{xx}$ & $\mathrm{xx}$ & 0.55 & 0.5 \\
\hline ALB1 <0.2 & 75 & & 25 & & & & 0.45 & 0.5 \\
\hline ALB1 $0.2-2$ & 72 & & 28 & & $\mathrm{x}$ & $\mathrm{x}$ & 0.35 & 0.35 \\
\hline ALB2 $<0.2$ & 71 & & 29 & & & & 0.5 & 0.5 \\
\hline ALB2 $0.2-2$ & 71 & & 29 & & $\mathrm{x}$ & $\mathrm{x}$ & 0.4 & 0.35 \\
\hline ALB2 $<2$ & 68 & & 32 & & $\mathrm{xx}$ & $\mathrm{xx}$ & 0.35 & 0.35 \\
\hline ATT $<0.2$ & 76 & & 24 & & & & 0.45 & 0.45 \\
\hline ATT $0.2-2$ & 65 & & 35 & & $\mathrm{x}$ & $\mathrm{x}$ & 0.35 & 0.35 \\
\hline STC $<0.2$ & 90 & 10 & & & & & 0.55 & 0.6 \\
\hline STC $0.2-2$ & 96 & 4 & & & & & 0.4 & 0.45 \\
\hline STC $<2$ & 89 & 5 & 6 & & & & 0.45 & 0.45 \\
\hline $\mathrm{BOH}<0.2$ & 41 & 59 & & & & & 0.75 & 0.8 \\
\hline BOH $0.2-2$ & 37 & 63 & & & & & 0.75 & 0.8 \\
\hline $\mathrm{BOH}<2$ & 51 & 42 & 7 & & & & 1.05 & \\
\hline LER $<0.2$ & 44 & 56 & & & & & 1.0 & 0.9 \\
\hline LER $0.2-2$ & 53 & 32 & 15 & & $\mathrm{x}$ & & 0.7 & 0.65 \\
\hline LER <2 & 53 & 28 & 19 & & $\mathrm{xx}$ & & 0.55 & 0.5 \\
\hline UTH $<0.2$ & 78 & 22 & $?$ & & $\mathrm{x}$ & & 0.8 & 0.9 \\
\hline UTH $0.2-2$ & 71 & 29 & & & $\mathrm{x}$ & & 0.7 & 0.65 \\
\hline $\mathrm{UTH}<2$ & 71 & 29 & & & $\mathrm{xx}$ & & 0.6 & 0.55 \\
\hline \multicolumn{9}{|c|}{ After Freezing/Thawing and Crushing } \\
\hline $\mathrm{LETb}<0.2$ & 56 & 15 & 19 & 10 & & & 0.9 & 0.9 \\
\hline LETb $0.2-2$ & 52 & 26 & 9 & 13 & $\mathrm{xx}$ & & 0.85 & 0.8 \\
\hline $\mathrm{HACb}<0.2$ & 73 & 27 & & & & & 0.55 & 0.55 \\
\hline $\mathrm{HACb} 0.2-2$ & 82 & 18 & & & $\mathrm{x}$ & $\varepsilon$ & 0.5 & 0.5 \\
\hline ALB $1 \mathrm{~b}<0.2$ & $\mathrm{xx}$ & & $\mathrm{x}$ & & & & 0.45 & 0.4 \\
\hline ALB1b $0.2-2$ & 69 & & 31 & & & & 0.35 & 0.3 \\
\hline $\mathrm{ATTb}<0.2$ & $\mathrm{xx}$ & & $\mathrm{x}$ & & & & 0.45 & 0.45 \\
\hline ATTb $0.2-2$ & 67 & 33 & $\varepsilon$ & $\varepsilon$ & & & 0.3 & 0.25 \\
\hline
\end{tabular}

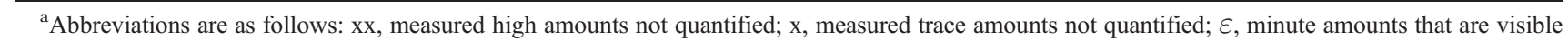
but too small to be quantified; ?, questionable occurrence.

consolidate the choice of the selected gentle crushing and treatment with acetic acid for all samples.

[26] The K-Ar data of the $<0.2 \mu \mathrm{m}$ fractions range from $293 \pm 12 \mathrm{Ma}(\mathrm{LET})$ to $359 \pm 8 \mathrm{Ma}$ (HAM; see Table 3$)$ and are younger than the stratigraphic age of the samples, indicating the dominant authigenic nature of the illite-type material. The relation between $\mathrm{K}-\mathrm{Ar}$ data lithology and illite crystallinity shows a general trend of increasing apparent age with decreasing ICI (=increasing recrystallization degree; see Figure 4). With the exception of the sample LER, the $<0.2 \mu \mathrm{m}$ fractions from clastic rocks with low ICI of 0.4 to $0.6^{\circ}(2 \Theta)$, yield higher apparent ages (331 $\mathrm{Ma} \pm 8$ to $345 \mathrm{Ma} \pm 9$ ) than the $<0.2 \mu \mathrm{m}$ fractions from carbonate rocks (293 $\pm 12 \mathrm{Ma}$ to $320 \pm 8 \mathrm{Ma})$, where the ICI are comparably high at 0.55 to $0.9^{\circ}(2 \Theta)$. The relationship between ICI and $\mathrm{K}$-Ar data could result from a preferential loss of ${ }^{40} \mathrm{Ar}$ from less crystallized illite with high ICI after a single crystallization event at $\sim 350$ Ma. However, the group of Middle Devonian clastics does not show that correlation, while higher K-Ar data and lower ICI may reflect a significant contamination by detrital components. To identify any possible loss of radiogenic ${ }^{40} \mathrm{Ar}$ or possible occurrence of detritals, the K-Ar dates were examined using isochron plots.

[27] Mixtures of two or more mineral parageneses with different formation ages or any significant loss of radiogenic ${ }^{40} \mathrm{Ar}$ from illite lattices can basically be identified by the ${ }^{40} \mathrm{Ar} /{ }^{36} \mathrm{Ar}$ intercept of a regression line in a ${ }^{40} \mathrm{Ar} /{ }^{36} \mathrm{Ar}$ versus ${ }^{40} \mathrm{~K} /{ }^{36} \mathrm{Ar}$ plot, and by the more or less pronounced scatter of the data along the regression line. As the proportions of the different mineral parageneses or the amounts of ${ }^{40} \mathrm{Ar}$ lost by diffusion are likely to vary from sample to sample, the resulting regression is a mixing line in a ${ }^{40} \mathrm{Ar} /{ }^{36} \mathrm{Ar}$ versus ${ }^{40} \mathrm{~K} /{ }^{36} \mathrm{Ar}$ plot, with a coefficient depending on the scatter. 

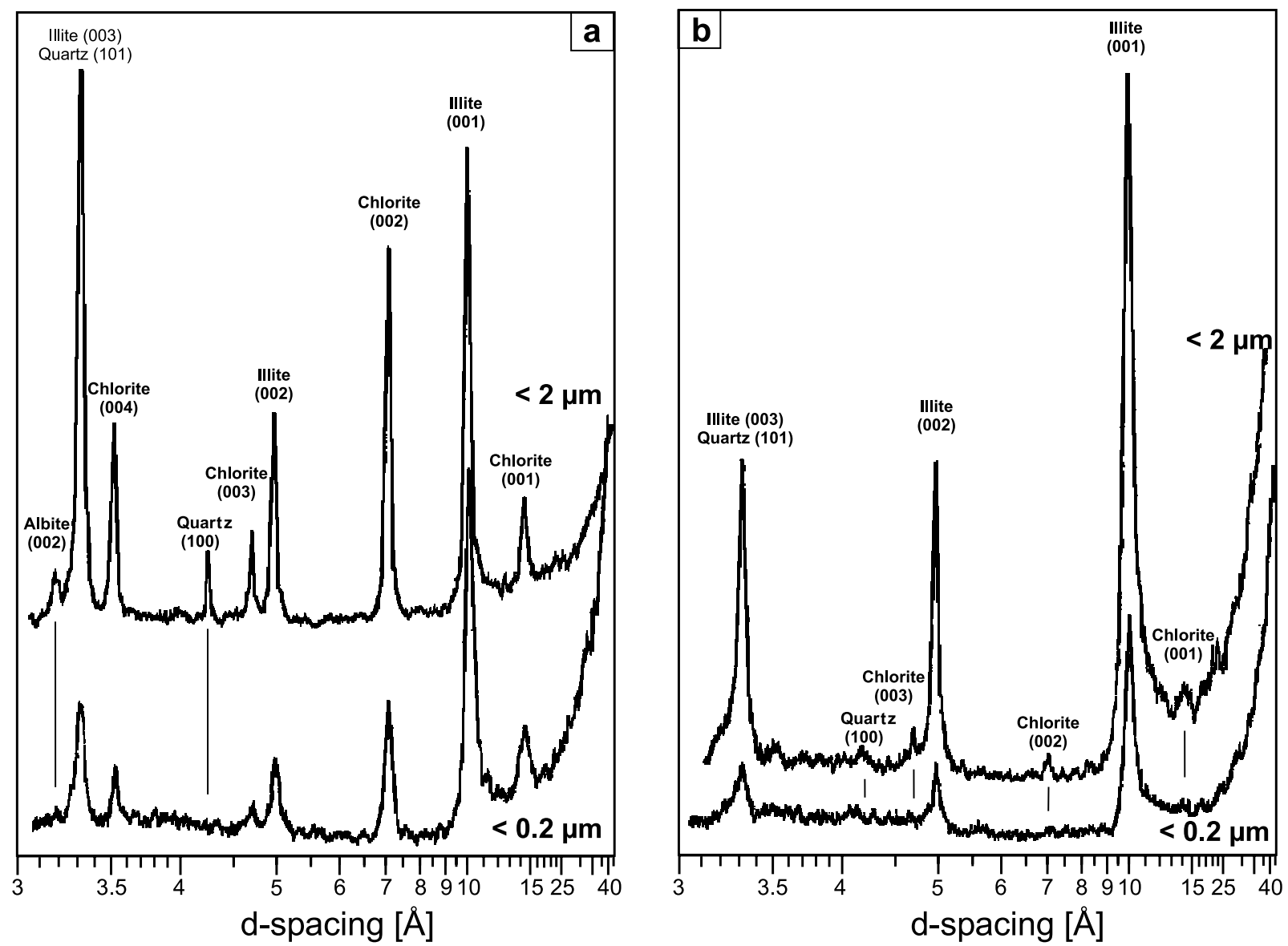

Figure 3. XRD patterns of the air-dried $<2$ and $<0.2 \mu \mathrm{m}$ size fractions of (a) the sandstone ALB 3 and (b) the carbonate STC. Notice that the amounts of detritals such as quartz and albite decrease significantly in the $<0.2 \mu \mathrm{m}$ fractions.

Table 3. K-Ar Data of Clay Fractions of All Samples ${ }^{\mathrm{a}}$

\begin{tabular}{|c|c|c|c|c|c|c|}
\hline Sample & $\mathrm{K}_{2} \mathrm{O}(\%)$ & ${ }^{40} \mathrm{Ar}^{*}(\%)$ & ${ }^{40} \mathrm{Ar} *\left(\mathrm{cc} / \mathrm{gx} 10^{-6}\right)$ & ${ }^{40} \mathrm{Ar}{ }^{136} \mathrm{Ar}$ & ${ }^{40} \mathrm{~K} /{ }^{36} \mathrm{Ar}\left(10^{-3}\right)$ & Age Ma $(+2 s)$ \\
\hline \multicolumn{7}{|c|}{ After Crushing and Treatment With Acetic Acid } \\
\hline LET & 3.63 & 49.43 & 37.29 & $584(6)$ & $15.53(0.20)$ & $293.4(12)$ \\
\hline $\mathrm{HAC}$ & 4.13 & 53.58 & 45.96 & $637(2)$ & $16.92(0.06)$ & $315.8(12)$ \\
\hline BRU & 5.68 & 93.78 & 67.37 & $4747(26)$ & $201.8(1.7)$ & 334.9 (7.6) \\
\hline HAM & 6.61 & 96.85 & 85.00 & $9382(24)$ & $369.1(1.5)$ & $359.0(7.8)$ \\
\hline NEU & 5.24 & 94.92 & 61.75 & $5822(50)$ & $250.4(3.6)$ & $333.0(7.6)$ \\
\hline OLP & 4.60 & 91.88 & 50.92 & $3640(23)$ & $163.6(1.6)$ & $314.4(7.4)$ \\
\hline ALB1 & 6.70 & 92.00 & 81.42 & $3691(14)$ & $151.3(0.8)$ & $342.2(7.8)$ \\
\hline ALB3 & 6.03 & 95.01 & 71.23 & $5920(114)$ & $254.1(6.8)$ & $333.7(7.5)$ \\
\hline ATT & 6.03 & 92.88 & 70.54 & $4148(64)$ & $177.8(3.8)$ & $330.6(7.5)$ \\
\hline STC & 5,00 & 87.23 & 56.42 & $2315(14)$ & $97.69(1.13)$ & $319.8(7.8)$ \\
\hline $\mathrm{BOH}$ & 8.48 & 98.69 & 94.21 & $22501(64)$ & $836.6(3.6)$ & $315.3(6.6)$ \\
\hline LER & 4.56 & 82.00 & 53.64 & $1642(4)$ & $62.77(0.23)$ & $332.2(8.7)$ \\
\hline UTH & 6.22 & 96.22 & 67.52 & 7827 (27) & $362.0(6.0)$ & $308.7(6.8)$ \\
\hline \multicolumn{7}{|c|}{ After Freezing/Thawing and Crushing } \\
\hline LETa $(<2 \mu \mathrm{m})$ & 1.71 & 56.35 & 21.30 & $677(3)$ & $16.98(0.21)$ & $350.2(13)$ \\
\hline LETb & 4.08 & 27.55 & 43.42 & $408(2)$ & $5.85(0.02)$ & $303.2(22)$ \\
\hline $\mathrm{HACa}(<2 \mu \mathrm{m})$ & 2.37 & 31.85 & 27.41 & $434(1)$ & $6.62(0.05)$ & $327.3(21)$ \\
\hline $\mathrm{HACb}$ & 3.76 & 40.86 & 45.32 & $500(1)$ & $9.36(0.04)$ & $339.7(17)$ \\
\hline ALB1a $(<2 \mu \mathrm{m})$ & 5.46 & 93.10 & 76.14 & $4285(82)$ & $158.5(4.3)$ & $387.9(8.9)$ \\
\hline ALB1b & 6.32 & 96.32 & 80.19 & $8026(43)$ & $337.2(3.7)$ & $356.2(7.8)$ \\
\hline $\operatorname{ATTa}(<2 \mu \mathrm{m})$ & 5.07 & 92.80 & 66.85 & $4106(13)$ & $160.1(0.9)$ & $368.8(8.6)$ \\
\hline ATTb & 5.50 & 84.57 & 67.46 & $1916(5)$ & $73.17(0.29)$ & $345.3(8.6)$ \\
\hline
\end{tabular}

${ }^{\mathrm{a} U n l e s s}$ stated otherwise, the $<0.2 \mu \mathrm{m}$ fractions were used for age determination. 


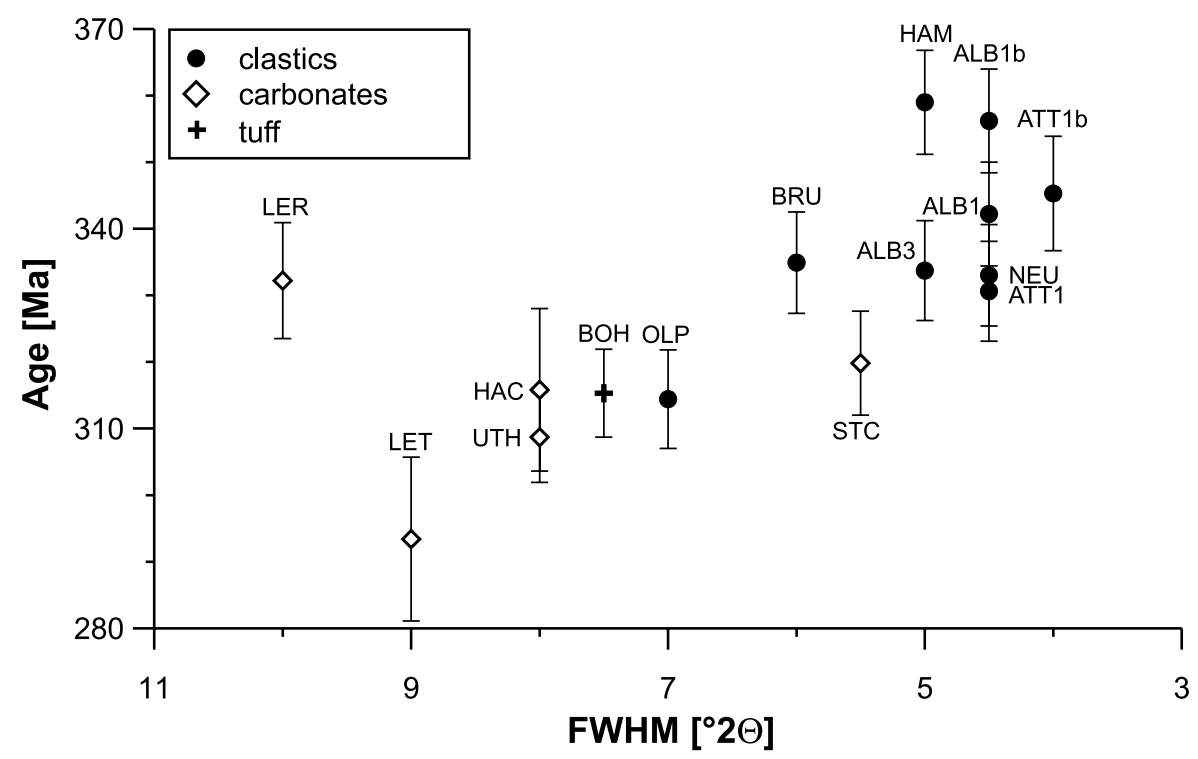

Figure 4. Plot of K-Ar apparent ages versus FWHM (illite crystallinity index) of the $10 \AA$ illite peak. Except for sample LER, the samples follow a general trend of increasing K-Ar apparent age with decreasing ICI (=increasing crystallinity). See section 5.1 for additional information.

The ${ }^{40} \mathrm{Ar} /{ }^{36} \mathrm{Ar}$ intercept of the mixing line is likely to be different from initial ${ }^{40} \mathrm{Ar} /{ }^{36} \mathrm{Ar}$ ratio of mineral parageneses, which is considered to be similar to the present-day atmospheric ${ }^{40} \mathrm{Ar} /{ }^{36} \mathrm{Ar}$ ratio (295.5; see Nier [1950]). As stated, meaningful isochron arrays should also have Mean Square Weight Deviates (MSWD) close to unity, as the scatter around the line should be limited. Owing to the limited number of samples in a normal data set, the MSWD is often larger than 1.0, and Brooks et al. [1972] believe that 2.5 is an acceptable cutoff for the definition of an isochron. However, it should be kept in mind, that natural inhomogeneity of sediments may also cause data scatters, and consequently higher MSWD values.

[28] Here, the K-Ar data of most samples fall on or close to one of two regression lines in a ${ }^{40} \mathrm{Ar} /{ }^{36} \mathrm{Ar}$ versus ${ }^{40} \mathrm{~K} /{ }^{36} \mathrm{Ar}$ plot. Both regression lines yield low MSWD values and initial ${ }^{40} \mathrm{Ar} /{ }^{36} \mathrm{Ar}$ ratios close to the present-day value (295.5), which are given by the intercept of the regression line with the ordinate. These regression lines can, therefore, be interpreted as isochrons (isochrons A and $\mathrm{B}$; see Figure 5). Isochron A consists in the data points of the $<0.2 \mu \mathrm{m}$ fractions of the Middle Devonian clastics (ALB1, ATT1, ATT1b, BRU, NEU and ALB3), yielding an age of $348 \pm 7 \mathrm{Ma}$. The initial ${ }^{40} \mathrm{Ar} /{ }^{36} \mathrm{Ar}$ ratio is $284 \pm 40$ and the MSWD is close to unity (0.97). It shall also be mentioned that the fractions ATT1 and ATT1b, which both were used for the calculation of isochron $\mathrm{A}$, were extracted from the same sample by different separation procedures and consequently are not strictly independent. If ATT1b is omitted, the resulting isochron yields larger uncertainties $\left(333 \pm 22 \mathrm{Ma}\right.$, initial ${ }^{40} \mathrm{Ar}{ }^{36} \mathrm{Ar}=473 \pm 220$ and MSWD $=$ 0.42 ), because all other data points are relatively grouped away from intercept. Owing to the large error, the age is not significantly different from that of isochron A. Isochron B is defined by the $<0.2 \mu \mathrm{m}$ fractions of the Upper Devonian and Lower Carboniferous carbonates (LET, HAC, STC and UTH) and one sample from Namurian greywackes (OLP), and it yields an age of $324 \pm 3 \mathrm{Ma}$, a MSWD of 3.5 and an initial ${ }^{40} \mathrm{Ar} /{ }^{36} \mathrm{Ar}$ of $280 \pm 35$. The observation of two isochrons $\mathrm{A}$ and $\mathrm{B}$ with ${ }^{40} \mathrm{Ar} /{ }^{36} \mathrm{Ar}$ ratios close to the present-day atmospheric value and the comparable low MSWD values can be considered to reflect the presence of two generations of illite: an older in Middle Devonian clastics (identified as illite generation A) and a later in the Upper Devonian and Carboniferous carbonates and greywackes (identified as illite generation B).

[29] Four samples do not follow the observed trends and were discarded in the isochron calculations. The clay fractions of two sandstone samples (ALB1b, HAM; see Figure 5) plot clearly above isochron A. This could be caused either by the occurrence of an older paragenesis of $\mathrm{K}$-bearing minerals or by excess ${ }^{40} \mathrm{Ar}$ during illite formation [Clauer, 2006, and references therein]. However, the clay fraction ALB1, which was separated from the same rock sample as ALB1b, fits isochron A and shows no evidence for excess ${ }^{40} \mathrm{Ar}$ during illite formation. Furthermore, such a mechanism is expected to affect other samples having a similar lithology such as BRU, or provenance such as ALB3, which is not the case. Therefore, the more likely cause for the high ${ }^{40} \mathrm{Ar}$ contents and high $\mathrm{K}-\mathrm{Ar}$ apparent ages of the illite fractions ALB1b and HAM is a varied but limited contamination by small amounts of detrital material, which may be due to sample preparation, especially slight over-crushing. For both samples, the ICI is not different than for other samples of similar lithologies, which excludes occurrence of significant amounts of detrital muscovite. The high $\mathrm{K}-\mathrm{Ar}$ data could also have been caused by detrital $\mathrm{K}$ feldspar, although $\mathrm{K}$ feldspar reflections were not identified by XRD. The case of the $<0.2 \mu \mathrm{m}$ fraction of carbonate LER is different by the fact that the data point plots between the two isochron trends (Figure 5), suggesting that it could belong to each of them. Although the characteristics of isochron B do not change significantly when including sample LER in the calculation $(323 \pm 5.5 \mathrm{Ma}$, initial 


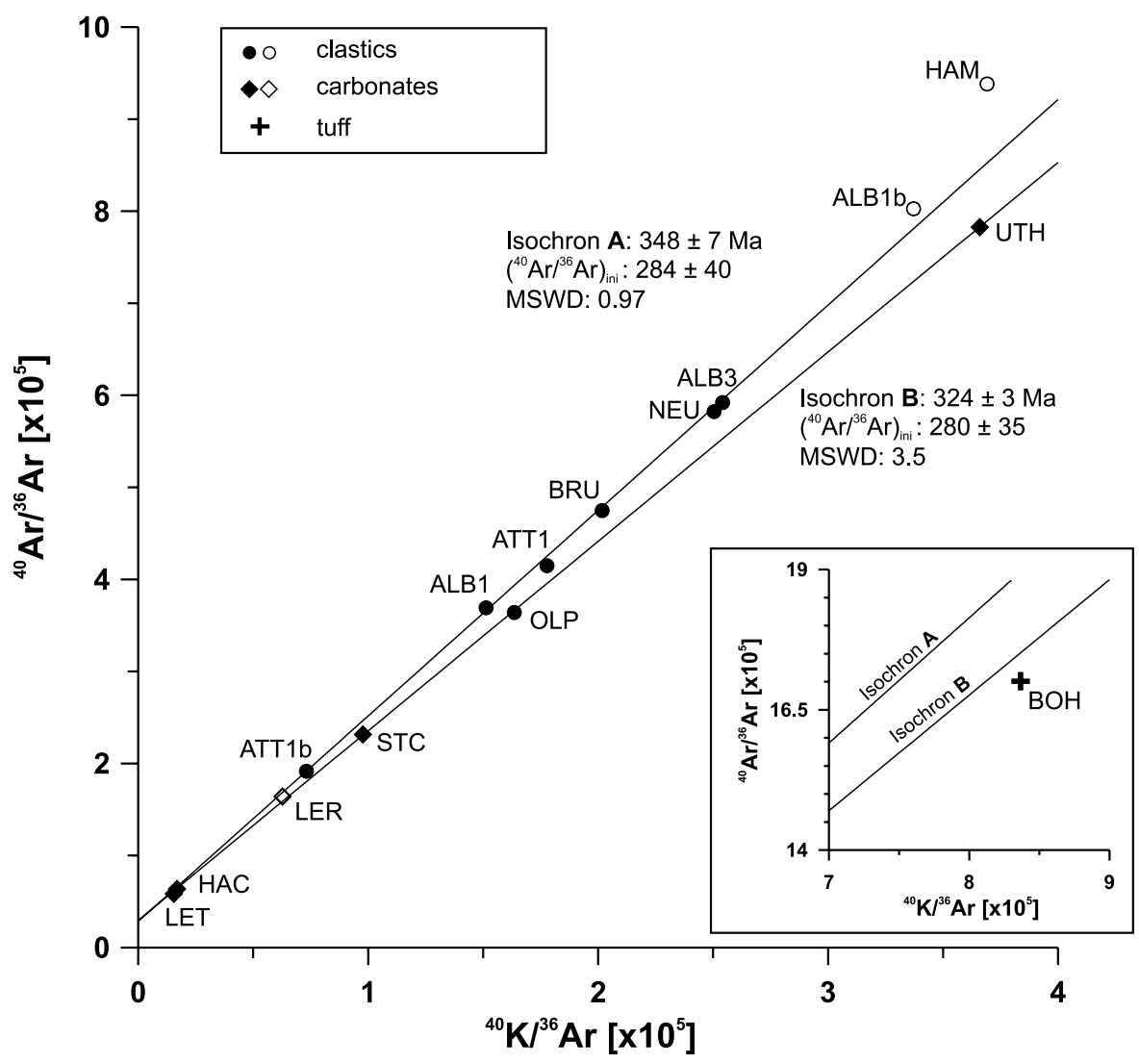

Figure 5. K-Ar isochron plot for the data of the $<0.2 \mu \mathrm{m}$ fractions. The ALB1, HAM, and LER fractions (open symbols) contaminated by detritals were not used for isochron calculations as well as that of $\mathrm{BOH}$ (insert). See section 5.1 for additional information.

$\left.{ }^{40} \mathrm{Ar} /{ }^{36} \mathrm{Ar}=297 \pm 57\right)$, the MSWD becomes as high as 16. Here, the cause for the high ${ }^{40} \mathrm{Ar}$ content and $\mathrm{K}-\mathrm{Ar}$ apparent age is ambiguous. Detrital contamination is unlikely, since the carbonate contains almost no siliciclastic material. On the other hand, no evidence for inherited ${ }^{40} \mathrm{Ar}$ is observed in the clay fraction from the carbonate sample UTH, which was sampled only a few $\mathrm{km}$ further east.

[30] The $<0.2 \mu \mathrm{m}$ fraction of the Middle Devonian $\mathrm{BOH}$ tuff from Wittgenstein syncline (WS in Figure 1) yields the highest $\mathrm{K}_{2} \mathrm{O}$ content of all samples $(8.48 \mathrm{wt} \%$ ) as well as exceptionally high ${ }^{40} \mathrm{Ar} /{ }^{36} \mathrm{Ar}$ and ${ }^{40} \mathrm{~K} /{ }^{36} \mathrm{Ar}$ ratios (Table 3). The data point clearly plots below isochron B (insert of Figure 5), which is consistent with the low apparent $\mathrm{K}-\mathrm{Ar}$ age. This younger value is thought to reflect either some diffusive loss of ${ }^{40} \mathrm{Ar}$ from an illite generation, which originally may have had an isotope composition similar to that of the clastic samples plotting on isochron A or B, or a slow crystallization already reported in such lithologies [Clauer et al., 1997]. Reuter [1987] reported relatively younger $\mathrm{K}-\mathrm{Ar}$ ages for small-sized illite fractions of tuff layers $(<0.63 \mu \mathrm{m})$, while the K-Ar data of coarser illite fractions from the same tuffs agree with those of the same illite size fractions from associated metapelites. She concluded that the $<0.63 \mu \mathrm{m}$ illite fractions of the tuffs experienced diffusive loss of radiogenic ${ }^{40} \mathrm{Ar}$ during a long-lasting decrease of the metamorphic temperatures, and that the K-Ar data have no geologic significance. In a study on similar material in diagenetic conditions, Clauer et al. [1997] suggested that the difference in the K-Ar ages points to the duration of illitization as it is strictly dependent on the $\mathrm{K}$ supply in such low-porous volcanic rocks.

\subsection{REE Geochemistry of the $<0.2 \mu \mathrm{m}$ Fractions and Leachates}

[31] The NASC-normalized REE patterns of the untreated $<0.2 \mu \mathrm{m}$ fractions are generally flat, but show varied amounts (see Table 4 and Figure 6). Most of the size fractions from clastics contain less REE than the NASC (clay/NASC $=0.5-0.8$ ), reflecting dilution effects by quartz. The NASC-normalized REE contents of the carbonate rocks $(0.3-1.5)$ show significant variations, which may result from occurrence of varying amounts of REE-poor minerals (dolomite, calcite, quartz). Beside these differences in REE contents mainly controlled by the rock facies, the patterns from two groups of clay fractions representing the two illite generations A and B are not significantly different. A few samples from both groups outline an increase in the heavy REEs (HREEs), which is most pronounced for the carbonate UTH and is probably related to the presence of organic matter. Sample LET is slightly enriched in middle REEs (MREEs $=\mathrm{Sm}, \mathrm{Eu}, \mathrm{Gd}, \mathrm{Tb}$ ), the variations of $\mathrm{Ce}$ and Eu being generally not significant, except for sample LER that yields a negative $\mathrm{Ce}$ anomaly.

[32] The amounts of REE in the leachates are rather low and range from $0.4 \%$ to $4.3 \%$ of the total REEs in the $<0.2$ $\mu \mathrm{m}$ fractions (Table 5). It can, therefore, be assumed that most of the REEs in the small size fractions is carried by minerals that are not dissolved during the leaching proce- 
Table 4. REE Contents of the Untreated $<0.2 \mu \mathrm{m}_{\text {Fractions }}{ }^{\mathrm{a}}$

\begin{tabular}{|c|c|c|c|c|c|c|c|c|c|c|c|c|c|c|}
\hline \multicolumn{15}{|c|}{ After Crushing and Treatment With Acetic Acid } \\
\hline LET & 23.1 & 49.6 & 7.47 & 34.3 & 7.66 & $1.73^{\circ}$ & 6.12 & 0.99 & 5.87 & 1.21 & 3.15 & 0.51 & 2.88 & 0.45 \\
\hline HAC & 40.3 & 84.2 & 9.83 & 40.2 & 8.18 & 1.82 & 6.88 & 1.21 & 7.33 & 1.55 & 4.01 & 0.66 & 3.68 & 0.51 \\
\hline BRU & 21.5 & 47.2 & 5.93 & 23.4 & 4.61 & 1.02 & 3.33 & 0.54 & 3.10 & 0.66 & 1.90 & 0.32 & 2.32 & 0.35 \\
\hline HAM & 30.4 & 63.3 & 7.16 & 25.8 & 4.49 & 0.98 & 3.43 & 0.54 & 3.28 & 0.68 & 2.07 & 0.36 & 2.54 & 0.40 \\
\hline NEU & 26.8 & 59.0 & 6.78 & 25.6 & 5.54 & 1.33 & 4.66 & 0.79 & 4.75 & 0.96 & 2.75 & 0.46 & 2.83 & 0.42 \\
\hline OLP & 26.5 & 54.9 & 6.45 & 24.6 & 5.14 & 1.20 & 4.05 & 0.65 & 3.97 & 0.87 & 2.50 & 0.46 & 2.92 & 0.44 \\
\hline ALB1 & 16.9 & 37.7 & 3.97 & 15.1 & 3.59 & 0.87 & 3.01 & 0.58 & 3.65 & 0.78 & 2.20 & 0.43 & 2.61 & 0.40 \\
\hline ALB2 & 21.4 & 47.6 & 6.35 & 26.9 & 6.66 & 1.30 & 5.21 & 0.98 & 5.91 & 1.15 & 3.08 & 0.51 & 2.90 & 0.38 \\
\hline ATT & 16.3 & 39.3 & 4.42 & 17.7 & 4.05 & 0.92 & 3.28 & 0.57 & 3.77 & 0.78 & 2.05 & 0.39 & 2.19 & 0.34 \\
\hline STC & 12.9 & 27.0 & 2.84 & 10.6 & 2.28 & 0.53 & 2.12 & 0.27 & 2.36 & 0.44 & 1.52 & 0.21 & 1.82 & 0.20 \\
\hline BOH & 18.8 & 50.8 & 5.47 & 19.9 & 5.26 & 0.34 & 4.64 & 1.12 & 7.47 & 1.38 & 3.77 & 0.73 & 4.41 & 0.67 \\
\hline LER & 18.3 & 26.9 & 3.23 & 12.3 & 2.50 & 0.59 & 2.27 & 0.37 & 2.45 & 0.55 & 1.44 & 0.27 & 1.49 & 0.24 \\
\hline UTH & 10.1 & 24.4 & 2.50 & 10.0 & 2.24 & 0.44 & 2.23 & 0.45 & 3.20 & 0.75 & 2.25 & 0.43 & 2.49 & 0.36 \\
\hline \multicolumn{15}{|c|}{ After Freezing/Thawing and Crushing } \\
\hline LETb & 8.38 & 12.4 & 1.50 & 6.00 & 1.58 & 0.53 & 1.79 & 0.44 & 3.48 & 0.84 & 2.59 & 0.50 & 3.04 & 0.46 \\
\hline $\mathrm{HACb}$ & 28.4 & 42.9 & 4.73 & 15.9 & 2.31 & 0.66 & 2.05 & 0.43 & 3.18 & 0.80 & 2.65 & 0.53 & 3.28 & 0.50 \\
\hline ALB1b & 15.0 & 29.9 & 3.39 & 13.4 & 2.81 & 0.70 & 2.53 & 0.49 & 3.25 & 0.72 & 2.17 & 0.40 & 2.56 & 0.40 \\
\hline ATT1b & 16.0 & 34.2 & 4.03 & 15.9 & 3.06 & 0.72 & 2.64 & 0.47 & 3.17 & 0.67 & 1.96 & 0.35 & 2.28 & 0.33 \\
\hline
\end{tabular}

${ }^{\mathrm{a}} \mathrm{REE}$, rare earth elemental.

dure. The low amounts of soluble REEs in the clastics (Figure 7a) correspond to the low Fe leaching with the reagent used, reflecting in turn the presence of insoluble $\mathrm{Fe}$ chlorite. This suggests that the insoluble REEs are preferentially carried by Fe-rich clay minerals. Except for the LET and STC samples, the carbonates are characterized by high amounts of soluble Fe and REEs. Similarly, the absolute amounts of soluble Fe and REEs are correlated (except for the ALB3 and STC samples), confirming that most of the soluble REEs is related to Fe oxides (Figure $7 \mathrm{~b}$ ). For most, the Tm and Lu concentrations are below analytical detection limit (Table 5). Some of the REE are slightly more scattered than others (Figure 8), which could either be due to the variation in REE carriers, or to analytical problems. Sample
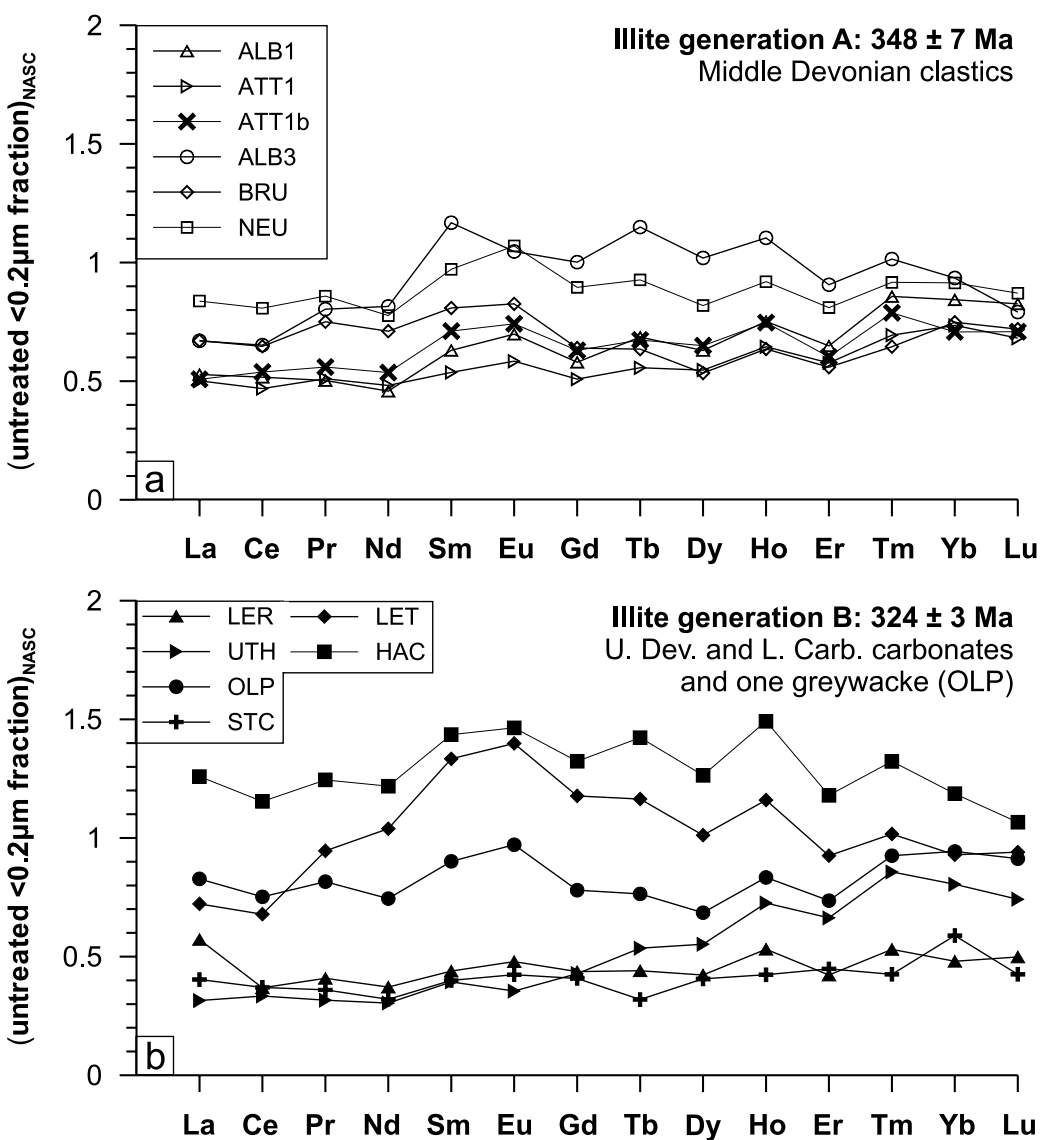

Figure 6. NASC-normalized rare earth elemental (REE) patterns of the untreated $<0.2 \mu \mathrm{m}$ fractions from illite generations A and B. See Figure 5 and section 5.2 for additional information. 

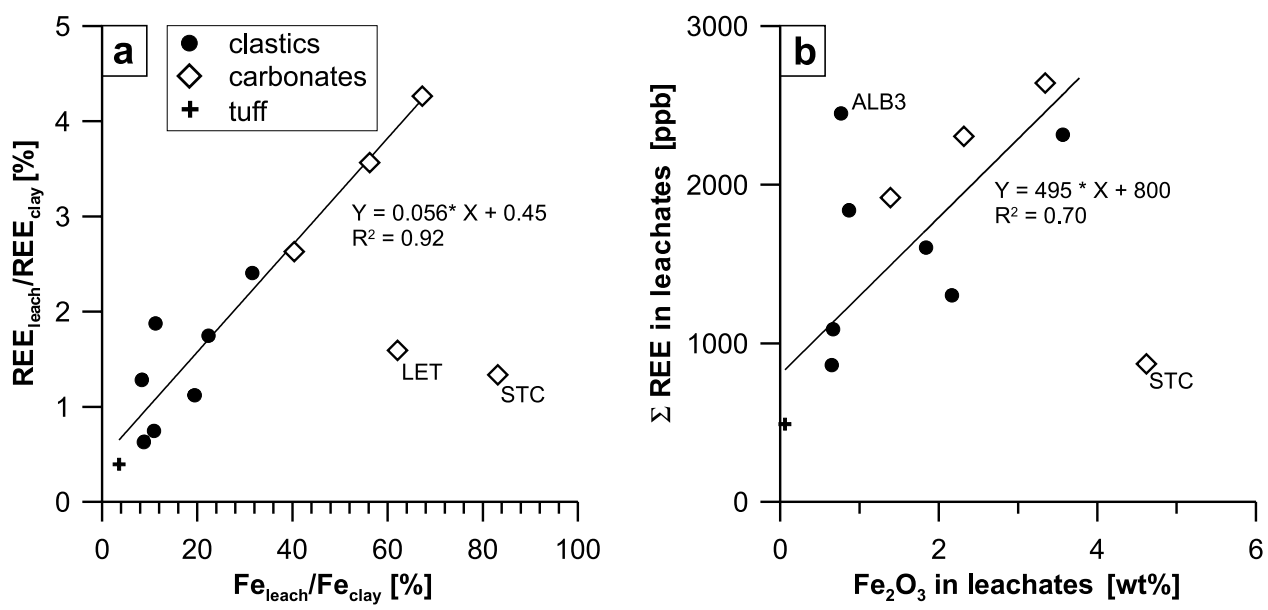

Figure 7. Relation between REE and Fe contents in the leachates.

LER was added to the group of the Upper Devonian and Lower Carboniferous carbonates and greywackes defining isochron B (324 $\pm 3 \mathrm{Ma})$ on the Figure 5. However, it should be remembered that the LER size fraction plots slightly above isochron $\mathrm{B}$ in a ${ }^{40} \mathrm{Ar} /{ }^{36} \mathrm{Ar}$ versus ${ }^{40} \mathrm{~K} /{ }^{36} \mathrm{Ar}$ plot.

[33] The REE patterns of the leachates are characterized by varying degrees of enrichment in MREEs (Figure 8), and they show significant differences among the samples characterized by the two generations of illite A and B. The enrichment in MREEs is more pronounced in the leachates of the Middle Devonian clastics (generation illite A of $348 \pm$ $7 \mathrm{Ma}$ ), while the patterns of the leachates from Upper Devonian and Lower Carboniferous carbonates and greywackes are generally flatter (generation illite B of $324 \pm 3$ Ma). This fractionation, which can be quantitatively described by the ratio of $\mathrm{Gd} / \mathrm{La}$, is directly correlated with the $\mathrm{Ba}$ content of the leachates. In the samples of group B with low MREE enrichment and low $\mathrm{Ba}$ contents, the ratio of $\mathrm{Gd} /$ $\mathrm{La}$ is negatively correlated to $\mathrm{Fe}_{2} \mathrm{O}_{3}$ and $\mathrm{CaO}+\mathrm{P}_{2} \mathrm{O}_{5}$. The relationship in the leachates is interpreted as reflecting two mineralization processes: an early crystallization of MREEenriched barite during formation of illite generation $\mathrm{A}$ and growth of $\mathrm{Fe}$ oxides and apatite with low $\mathrm{Gd} / \mathrm{La}$ ratios $(\leq 1)$ during formation of illite generation B. For most leachates, the variation in the $\mathrm{Ce}$ and Eu anomalies, which may occur in two valence states, is not significant. However, the ATT1, ALB1 and UTH leachates yield negative Eu anomalies, while leachate LET has a negative Ce anomaly. This is thought to reflect different reduction/oxidation conditions during precipitation of REE-carrying minerals, such as the Fe oxides and apatite.

\subsection{Leaching Experiments of the Fe-Bearing Mineral Phases}

[34] For efficiency control of the leaching procedure, the amount of magnetite in the samples was estimated using the anhysteretic susceptibility $\left(\mathrm{k}_{\mathrm{an}}\right)$ as a proxy. While the initial susceptibility $\mathrm{k}_{0}$ is controlled by all magnetic (ferro(i) -, para-, and dia-magnetic) material of the sample, $k_{a n}$ reflects only the amount of ferromagnetic minerals. It depends also on grain size and is about one order of magnitude greater in the $0.1 \mu \mathrm{m}$ magnetite grains than in $1 \mu \mathrm{m}$ grains [Dunlop and Özdemir, 1997]. Consequently, the mass-normalized anhysteretic susceptibility of a whole-rock sample is a good estimation for the magnetite content in the $<0.2 \mu \mathrm{m}$ fraction, where the magnetite grains are about $<0.12 \mu \mathrm{m}$ in size. Since the alternating field intensity during acquisition of the anhysteretic remanent magnetization (ARM) was set to

Table 5. REE Contents of the Leachates ${ }^{\mathrm{a}}$

\begin{tabular}{|c|c|c|c|c|c|c|c|c|c|c|c|c|c|c|}
\hline Sample & $\mathrm{La}(\mathrm{ppb})$ & $\mathrm{Ce}(\mathrm{ppb})$ & $\operatorname{Pr}(\mathrm{ppb})$ & $\mathrm{Nd}(\mathrm{ppb})$ & $\mathrm{Sm}(\mathrm{ppb})$ & $\mathrm{Eu}(\mathrm{ppb})$ & $\mathrm{Gd}(\mathrm{ppb})$ & $\mathrm{Tb}(\mathrm{ppb})$ & Dy (ppb) & Ho (ppb) & $\mathrm{Er}(\mathrm{ppb})$ & $\mathrm{Tm}(\mathrm{ppb})$ & $\mathrm{Yb}(\mathrm{ppb})$ & $\mathrm{Lu}(\mathrm{ppb})$ \\
\hline \multicolumn{15}{|c|}{ After Crushing and Treatment With Acetic Acid } \\
\hline BRU & 145 & 420 & 57.1 & 284 & 76.0 & 22.5 & 95.2 & 13.9 & 84.0 & 18.2 & 45.0 & BDL & 45.0 & BDL \\
\hline HAM & 168 & 426 & 47.8 & 234 & 50.5 & 17.1 & 54.2 & BDL & 45.1 & BDL & 28.0 & BDL & 20.8 & BDL \\
\hline NEU & 207 & 538 & 89.6 & 369 & 104 & 40.3 & 142 & 31.4 & 120 & 34.9 & 65.4 & 22.4 & 60.0 & 19.7 \\
\hline OLP & 121 & 290 & 43.2 & 201 & 53.8 & 12.5 & 55.7 & $\mathrm{BDL}$ & 45.1 & BDL & 22.1 & $\mathrm{BDL}$ & 19.2 & BDL \\
\hline ALB2 & 214 & 699 & 113 & 573 & 199 & 42.9 & 209 & 32.2 & 173 & 32.2 & 83.2 & 9.84 & 61.7 & 8.94 \\
\hline STC & 136 & 350 & 41.0 & 174 & 34.8 & BDL & 55.3 & BDL & 38.4 & 8.92 & 20.5 & BDL & 13.4 & BDL \\
\hline $\mathrm{BOH}$ & 74.0 & 181 & 21.8 & 88.0 & 23.5 & BDL & 30.5 & BDL & 33.1 & BDL & 22.6 & BDL & 16.6 & BDL \\
\hline LER & 259 & 546 & 113 & 515 & 127 & 28.6 & 138 & 166.1 & 93.8 & 16.1 & 39.3 & BDL & 25.0 & BDL \\
\hline UTH & 385 & 1079 & 128 & 561 & 126 & 17.0 & 112 & 14.3 & 95.1 & 17.9 & 55.6 & BDL & 48.4 & BDL \\
\hline \multicolumn{15}{|c|}{ After Freezing/Thawing and Crushing } \\
\hline LETn & 366 & 712 & 127 & 592 & 132 & 31.4 & 153 & 17.9 & 96.9 & 14.3 & 43.9 & BDL & 18.8 & BDL \\
\hline HACn & 1177 & 2010 & 871 & 1450 & 392 & 139 & 421 & 1166 & 343 & 117 & 184 & 82.3 & 132 & 69.2 \\
\hline ALB1n & 152 & 414 & 66.9 & 363 & 144 & 25.2 & 135 & 21.3 & 127 & 22.3 & 56.2 & 9.669 & 55.2 & 9.69 \\
\hline ATTn & 275 & 700 & 107 & 545 & 188 & 35.7 & 177 & 25.3 & 139 & 21.6 & 56.3 & BDL & 43.2 & BDL \\
\hline
\end{tabular}

${ }^{a}$ Amounts of all elements are in ppb (relative to the untreated $<0.2 \mu \mathrm{m}$ fractions). REE, rare earth elemental. BDL, below detection limit. 

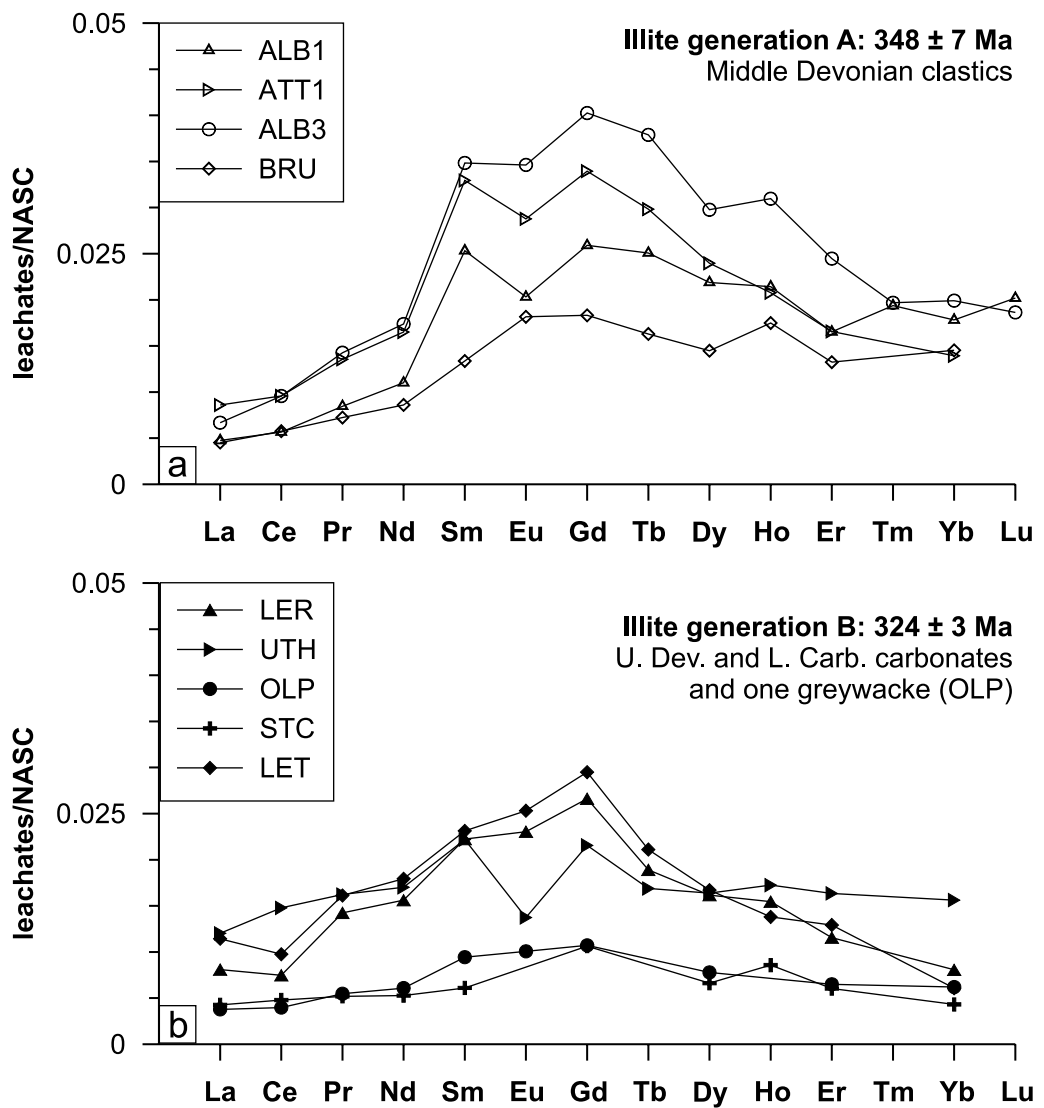

Figure 8. NASC-normalized REE patterns of the leachates from $<0.2 \mu \mathrm{m}$ fractions of generations A and B. See Figure 5 and section 5.2 for additional information.

$150 \mathrm{mT}$, only magnetic minerals with coercivities below $150 \mathrm{mT}$ (e.g., magnetite) contribute to $\mathrm{k}_{\mathrm{an}}$.

[35] For samples in which magnetite is the predominant ferro(i)magnetic mineral, the $\mathrm{Fe}_{2} \mathrm{O}_{3}$ content of the leachates is correlated to $\mathrm{k}_{\mathrm{an}}$. Considering natural inhomogeneities and effects from large magnetite grains that contribute to the ARM, which do not occur in the $<0.2 \mu \mathrm{m}$ fractions, this correlation is reasonably good $\left(\mathrm{r}^{2}=0.75\right.$; see Figure 9$)$. It means in turn that the magnetite minerals, which can carry a remanent magnetization, were not removed during the separation of the clay fractions, but were completely dissolved during the leaching process. In addition, the leachates for which the rock-magnetic experiments indicate an occurrence of hematite, contain more $\mathrm{Fe}_{2} \mathrm{O}_{3}$ than predicted by $\mathrm{k}_{\mathrm{an}}$ suggesting that hematite, which does not contribute to $\mathrm{k}_{\mathrm{an}}$, is also dissolved by the dithionite treatment. Although the relation between $\mathrm{k}_{\mathrm{an}}$ and the $\mathrm{Fe}_{2} \mathrm{O}_{3}$ content of the leachates shows that dithionite leaching is very effective in dissolving magnetite and hematite, $\mathrm{Fe}$ is not be completely removed, as minute amounts of leachate remain absorbed on the clay residue after centrifugation. In fact, the relative amount of leached $\mathrm{Fe}$ is controlled by the lithology and provenance of the samples (Table 6): it is generally higher than $50 \%$ for the clay material of carbonates $(40-83 \%)$, but significantly lower in that of clastics $(8-30 \%)$. The different degrees of Fe leaching indicate varying amounts of other Fe-bearing minerals in the different rock types and sampling areas, that are less or not soluble to dithionite. Fe chlorite

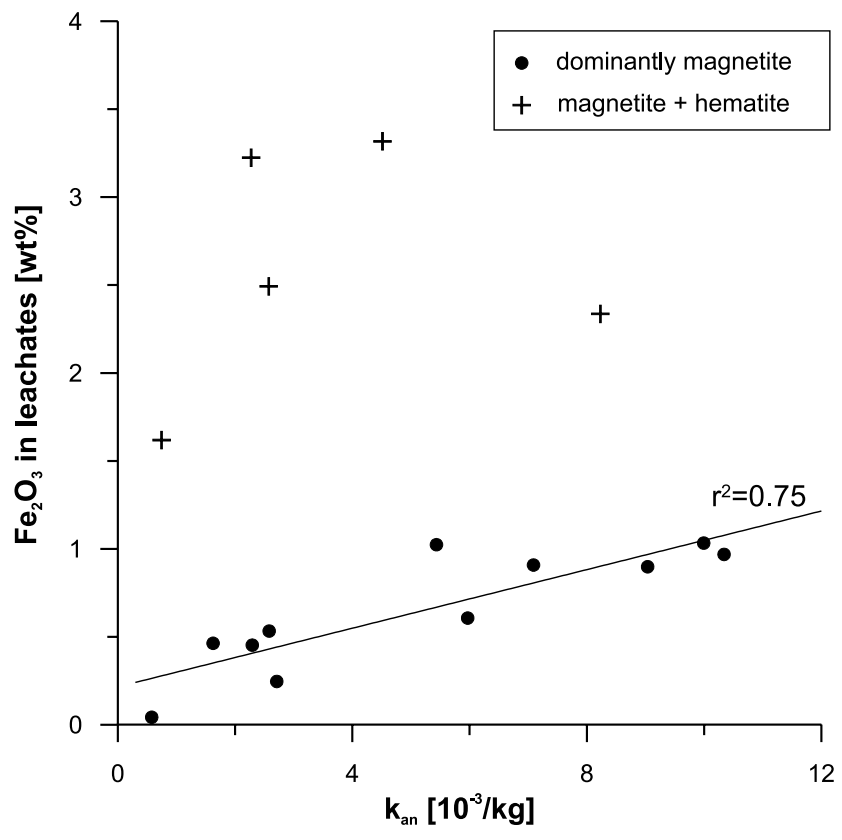

Figure 9. Relation between the $\mathrm{Fe}_{2} \mathrm{O}_{3}$ contents of the leachates and the mass-normalized anhysteretic susceptibility $\mathrm{k}_{\mathrm{an}}$ in samples with a predominant ferromagnetic mineral phase (circles). The samples containing hematite that does not contribute to $\mathrm{k}_{\mathrm{an}}$ are represented by the crosses. 
Table 6. Major and Some Trace Elemental Compositions of the Leachates ${ }^{\mathrm{a}}$

\begin{tabular}{|c|c|c|c|c|c|c|c|c|c|c|c|}
\hline Sample & $\mathrm{O} 2$ (wt \%) & $\mathrm{Al} 2 \mathrm{O} 3$ (wt \%) & $\mathrm{MgO}(\mathrm{wt} \%)$ & $\mathrm{CaO}$ (wt \%) & $\mathrm{Fe} 2 \mathrm{O} 3(\mathrm{wt} \%)$ & $\mathrm{MnO}(\mathrm{ppm})$ & $\mathrm{TiO} 2(\mathrm{ppm})$ & $\mathrm{K} 2 \mathrm{O}(\mathrm{ppm})$ & $\mathrm{P} 2 \mathrm{O} 5(\mathrm{ppm})$ & $\mathrm{Ba}(\mathrm{ppm})$ & Th $(\mathrm{ppb}$ \\
\hline \multicolumn{12}{|c|}{ After Crushing and Treatment With Acetic Acid } \\
\hline BRU & 0.10 & 0.64 & 0.10 & 0.25 & 2.16 & 151 & 15.8 & 903 & 236 & 189 & 238 \\
\hline HAM & 0.23 & 0.45 & 0.09 & 0.17 & 0.66 & 97.8 & 2.88 & 818 & 121 & 41.5 & 113 \\
\hline NEU & 0.25 & 0.48 & 0.13 & 0.24 & 0.87 & 114 & 16.1 & 601 & 175 & 41.9 & 161 \\
\hline OLP & 0.23 & 0.75 & 0.10 & 0.13 & 0.65 & 48.4 & 1.54 & 1026 & 86.5 & 59.5 & 50.8 \\
\hline ALB2 & 0.25 & 0.36 & 0.08 & 0.21 & 0.76 & 67.2 & 9.40 & 653 & 236 & 69.1 & 125 \\
\hline STC & 0.16 & 0.29 & 0.04 & 0.16 & 4.61 & 609 & 198 & 283 & 811 & 24.0 & 46.6 \\
\hline $\mathrm{BOH}$ & 0.17 & 0.49 & 0.14 & 0.24 & 0.06 & 12.3 & 5.74 & 1422 & $\mathrm{BDL}^{\mathrm{b}}$ & 266 & 165 \\
\hline LER & 0.38 & 0.34 & 0.17 & 0.48 & 1.38 & 11.7 & 13.8 & 769 & 215 & 23.4 & 271 \\
\hline UTH & 0.15 & 0.29 & 0.08 & 0.46 & 3.34 & 539 & 43.5 & 361 & 885 & 19.8 & 269 \\
\hline \multicolumn{12}{|c|}{ After Freezing/Thawing and Crushing } \\
\hline LETn & 0.20 & 0.10 & 0.08 & 0.35 & 2.31 & 114 & 0.09 & 276 & 1112 & 47.6 & 153 \\
\hline $\mathrm{HACn}$ & 0.25 & 0.26 & 0.02 & 0.13 & 1.48 & 10.8 & 15.5 & 858 & 2826 & 97.2 & 362 \\
\hline ALB1n & 0.32 & 0.44 & 0.06 & 0.26 & 1.84 & 67.7 & 3.58 & 617 & 1096 & 52.5 & 217 \\
\hline ATT1n & 0.20 & 0.25 & 0.07 & 0.23 & 3.56 & 91.0 & 97.3 & 519 & 714 & 58.3 & 490 \\
\hline
\end{tabular}

${ }^{\mathrm{a}}$ Amounts are in wt \%, ppm, and ppb (relative to the untreated $<0.2 \mu \mathrm{m}$ fractions) as indicated for each element.

${ }^{\mathrm{b}} \mathrm{BDL}$, below detection limit.

was identified by XRD; it certainly represents an important source of insoluble $\mathrm{Fe}$ in the siliciclastic rocks, while its absence in carbonates explains the higher degree of $\mathrm{Fe}$ leaching in those lithologies.

[36] Besides $\mathrm{Fe}_{2} \mathrm{O}_{3}$, the leachates contain significant amounts of other oxides such as $\mathrm{SiO}_{2}, \mathrm{Al}_{2} \mathrm{O}_{3}, \mathrm{MgO}, \mathrm{K}_{2} \mathrm{O}$, $\mathrm{CaO}$ and $\mathrm{P}_{2} \mathrm{O}_{5}$, indicating dissolution of other mineral phases during the leaching process. The sum of the released elements (besides $\mathrm{Fe}_{2} \mathrm{O}_{3}$ ) is quite constant in all samples (Table 6), providing a linear correlation $\left(\mathrm{r}^{2}=0.98\right)$ between the total amount of oxides and the total amount of $\mathrm{Fe}_{2} \mathrm{O}_{3}$ in all samples, meaning in turn that $\mathrm{Fe}_{2} \mathrm{O}_{3}$ is the determining oxide in the samples; the others being accessory. The $\mathrm{Al} / \mathrm{Si}$ ratios of the leachates show a wide variation $(0.63-7.7)$, being generally higher than for illite, smectite or chlorite, which are the most common clay minerals in the $<0.2 \mu \mathrm{m}$ fractions studied here. We consider this as a convincing proof against any dissolution or alteration of clay particles during the leaching procedure. The variations in the $\mathrm{Al} / \mathrm{Si}$ ratios rather reflect the occurrence of additional soluble amorphous silica and Al-oxi-hydroxides in varied proportions, mainly in the small size fractions. It should be noted that although the dissolved mineral phases yield a strong relationship among $\mathrm{Al}$ and $\mathrm{K}$, dissolution of $\mathrm{K}$ feldspar is not indicated either by the $\mathrm{Al} / \mathrm{K}$ ratios of the leachates.

[37] In the $\mathrm{Ca}, \mathrm{Fe}, \mathrm{Mg}$ ternary diagram, all leachates fall into a field including Fe-oxi-hydroxides, dolomite, calcite and apatite (Figure 10). This suggests that clay minerals and other silicates are not affected by the type of leaching used here, while oxi-hydroxides, carbonates, phosphates and sulfates are. It can be stated that the calcite contribution is minimal, since the clay fractions were treated with acetic

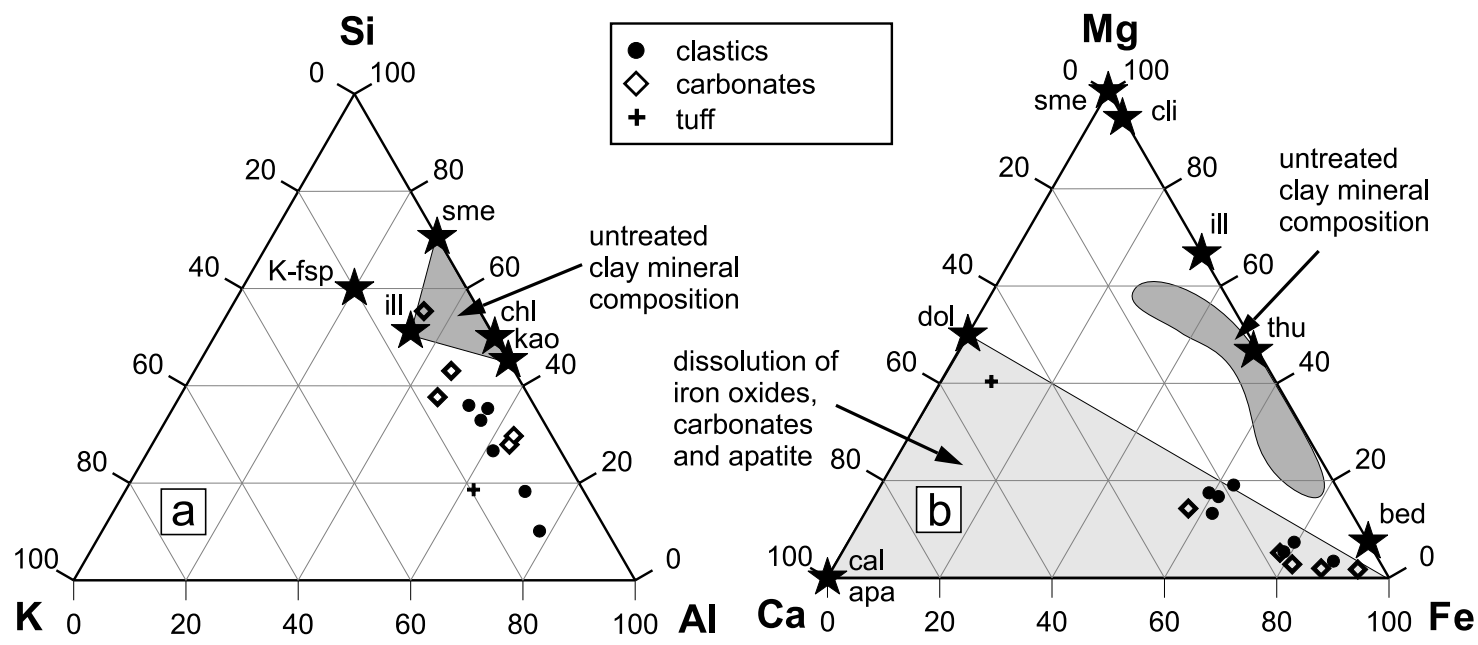

Figure 10. Ternary diagrams of $\mathrm{K}-\mathrm{Si}-\mathrm{Al}$ and of $\mathrm{Ca}-\mathrm{Mg}-\mathrm{Fe}$ in the leachates. (a) The leachates (symbols) yield higher $\mathrm{Si} / \mathrm{Al}$ ratios than the untreated $<0.2 \mu \mathrm{m}$ fractions (stippled area), while the $\mathrm{K} / \mathrm{Al}$ ratios are similar. (b) The $\mathrm{Ca}, \mathrm{Fe}$, and $\mathrm{Mg}$ contents of the leachates point to dissolutions of Fe-oxi-hydroxides, dolomite, calcite, and apatite (gray area). The untreated fractions are plotted in the stippled area. The stars represent average mineral compositions for: apa, apatite; bed, beidellite ( $\mathrm{Fe}$ smectite); cal, calcite; chl, chlorite; cli, clinochlore (Mg chlorite); dol, dolomite; kao, kaolinite; K-fsp, K feldspar; sme, smectite; thu, thuringite. 
acid during the preparation phase, before leaching. Consequently, it can be assumed that the leachates represent a mixture of Fe oxides and other soluble minerals in the $<0.2 \mu \mathrm{m}$ fractions. Fe-oxi-hydroxides are important carriers (scavengers) of REEs in sedimentation and diagenetic environments (e.g., Cullers et al. [1979] and many since). Analysis and interpretation of REE patterns in Fe oxide leachates represent, therefore, a potential method to characterize the geochemical events that induced authigenic formation of magnetic minerals. Since leachates consist in mixture of $\mathrm{Fe}$ oxides and other soluble minerals, it can be assumed that most of the REEs signatures are representative of authigenic mineral phases. This assumption is feasible for fine-grained $\mathrm{Fe}$ oxides and other highly soluble minerals of chemically remagnetized rocks, such as barite, which are likely to be affected during diagenetic crystallization associated with fluid migrations.

[38] Alternatively, detrital REE-rich minerals can significantly contaminate the authigenic REE patterns if present in the $<0.2 \mu \mathrm{m}$ fractions and dissolved during leaching [Honty et al., 2008]. Possible candidates for those REE-rich minerals are apatite, zircon and monazite, which were observed by SEM as accessory minerals in the clastic rocks. Zircon $\left(\mathrm{ZrSiO}_{4}\right)$ and other REE-carrying silicates (sphene, allanite) are very resistant to chemical weathering and unlikely to be dissolved during leaching. Contamination by detrital monazite $\left((\mathrm{Ce}, \mathrm{REE}) \mathrm{PO}_{4}\right)$ cannot be significant, since monazite is typically depleted in heavy REEs (HREEs) with a $\mathrm{Gd} / \mathrm{Yb}$ ratio of 27.2 , and it contains more than $6 \%$ Th [Lee and Bastron, 1967], while here the $\mathrm{Gd} / \mathrm{Yb}$ ratio ranges from 2 to 10 for most of the leachates, and the Th contents scatter between 50 and $500 \mathrm{ppb}$. Detrital apatite is more difficult to identify, since its trace elemental composition and REE pattern both vary significantly with the type of their initial magmatic host rocks [Belousova et $a l ., 2002]$ and sediments often contain mixtures of apatite detritus from different source areas. As the total content of REEs is not directly correlated to the $\mathrm{P}_{2} \mathrm{O}_{5}$ concentrations in the leachates from carbonate rocks $\left(\mathrm{r}^{2}=0.28\right)$, apatite appears not to be a major source of the REEs in the leachates from studied lithologies. It might be added that all apatite grains identified by SEM in the samples were larger than $5 \mu \mathrm{m}$, not being expected therefore to occur in the $<0.2 \mu \mathrm{m}$ fractions. At this point, a REE contamination of the leachates by detrital apatite cannot be completely ruled out, but it is thought to be unlikely.

\section{Discussion}

[39] A pervasive remagnetization predominantly carried by magnetite is identified in Late Paleozoic carbonate and clastic rocks from NE Rhenish Massif [Bachtadse et al., 1983; Wilken, 1995; Zwing et al., 2002]. The age of this remagnetization is well constrained to the 315-300 Ma time span by the age of deformation [Ahrendt et al., 1983] and the comparison of the resulting paleolatitudes for the region with its paleolatitudinal drift history [Van der Voo, 1990]. The concordance of the magnetic inclinations from entire area suggests that the rocks were remagnetized during a relatively short time period of only a few millions of years. The thermal stability of the remanence up to $\sim 550^{\circ} \mathrm{C}$, the comparably low paleotemperatures in the studied region and the short duration of the remagnetization event, favor the occurrence of a chemical remagnetization process [Zwing et al., 2002]. Authigenesis of magnetic minerals (magnetite) is identified by hysteresis ratios, magnetic viscosity and low-temperature behavior of the carbonate rocks [Zwing et al., 2005].

\subsection{Interpretation of Clay Mineralogy and Geochronology}

[40] The formation of authigenic mica-type sheet silicates is a common process during very low-grade metamorphism of sedimentary and volcanic rocks (Dunoyer de Segonzac [1969] and many others since). The thermally induced transition from illite-smectite mixed layer to illite-mica has been studied many times, being often used as an indicator for very low-grade conditions [Kübler, 1966]. The crystallographic-chemical changes during this transition induce modifications of the isotopic and geochemical signatures, which can be used to constrain the timing of and the conditions during diagenetic processes [e.g., Clauer and Chaudhuri, 1995, 1999]. In order to study a specific diagenetic event, successful separation of characteristic mineral generations is crucial, especially to identify the contamination from detrital micas and discard the corresponding size fractions in the isotopic study. In general, even if not a rule, the probability of the presence of contaminating minerals is decreasing when grain size decreases. Therefore, separation and characterization of successive illite generations is a fundamental step in the appropriate selection of size fractions for isotopic analysis. [41] The ${ }^{40} \mathrm{Ar} /{ }^{36} \mathrm{Ar}$ ratios close to the present-day value and the comparably low MSWD values represent strong evidences that the discussed isochrons A and B obtained here characterize two distinct generations of authigenic illite. This implies two different events of illite formation in the rocks: an older in the Middle Devonian clastics and a later in the Upper Devonian and Lower Carboniferous carbonates and Namurian greywackes. Furthermore, construction of both isochrons rules out the occurrence of mixings of detrital and authigenic components as well as the preferred loss of radiogenic ${ }^{40} \mathrm{Ar}$ from less crystallized illite in most of the samples.

[42] Since the ${ }^{40} \mathrm{Ar} /{ }^{36} \mathrm{Ar}$ intercepts are not significantly different from each other $(284 \pm 40$ and $280 \pm 35)$ and from present-day atmospheric ${ }^{40} \mathrm{Ar} /{ }^{36} \mathrm{Ar}$ ratio, we consider these ages to represent best the formation ages of the two illite generations. The clay fractions from clastics (ALB1, ATT1, ATT1b, BRU, NEU, ALB3) contain the oldest illite generation at $348 \pm 7 \mathrm{Ma}$ (illite generation $\mathrm{A}$ in Figure 6), which is significantly different from $\mathrm{K}-\mathrm{Ar}$ age for illite of the carbonates LET, HAC, LER, UTH, STC and greywacke OLP (illite generation B in Figure 6) at $324 \pm 3 \mathrm{Ma}$.

[43] The Middle Devonian clastics yield an illitization age at $348 \pm 7 \mathrm{Ma}$ probably connected to the major magmatic event at $\sim 340-330$ Ma in the Mid-German Crystalline Rise [Kreuzer and Harre, 1975; Todt et al., 1995] that was located closely the NE Rhenish Massif at that time [Franke, 2000]. During this event, fluids are thought to have released sulfates from sedimentary-exhalative deposits that were described along major synsedimentary fault zones [Werner, 1989]. The characteristic enrichment in MREEs of leachates with high $\mathrm{Ba}$ contents 
is probably inherited from those synsedimentary mineral deposits. The second illite formation at $324 \pm 3 \mathrm{Ma}$ is coeval to the northward migration of deformation through the Rhenish Massif, being only recorded by Upper Devonian and Lower Carboniferous rocks. This indicates that the metamorphic conditions were not sufficient to recrystallize the earlier illite generation in the more deeply buried Middle Devonian rocks. It is supported by the high ICI of the Upper Devonian and Lower Carboniferous rocks. However, it needs to be kept in mind that this boundary was folded during the Variscan deformation, which is outlined by the vitrinite reflectance being correlated to the stratigraphic units and by the $\mathrm{R}_{\max }$ isolines being folded and set off across the faults [Paproth and Wolf, 1973]. Consequently, the first illite generation and the vitrinite reflectance preserved a thermal state related to the maximum burial and the magmatic event in the Mid-German Crystalline Rise.

[44] The second illitization event is not significantly different from timing of the pervasive and syntectonic remagnetization. In contrast, remagnetization was not only restricted to the upper part of the fold and thrust belt, but it affected also the Middle Devonian strata, erasing any previous remagnetization possibly caused by the earlier thermal event. The younger illite generation is characterized by lower $\mathrm{Gd} / \mathrm{La}$ ratios in the leachates, which are thought to reflect crystallization of $\mathrm{Fe}$ oxides and apatite with flat NASC-normalized REE patterns. The regional pervasive migration of fluids is expected to homogenize the REE signatures of the soluble minerals, but the REE patterns of the leachates rather suggest an interference of two mineralizations possibly of different ages. The REE patterns from different samples also show variations of the $\mathrm{Eu}$ and $\mathrm{Ce}$ contents indicating varied oxidation-reduction conditions in the different lithologies. This observation is against a pervasive migration of orogenic fluids on a regional scale for remagnetization in the NE Rhenish Massif. In the Ardennes Massif, an Early Permian remagnetization was related to fluid migration during formation of Mississippi Valley-type deposits [Zegers et al., 2003]. The absence of such syn- to late-orogenic deposits in the NE Rhenish Massif further supports the evidence against a regional-size migration of orogenic fluids.

[45] A temporal relationship between clay diagenesis and remagnetization is observed in Upper Devonian and Lower Carboniferous rocks. On the other hand, remagnetization is not related to clay diagenesis in the Middle Devonian rocks, since the latter preserved an older diagenetic event. Therefore, the transformation of smectite into illite cannot account for the growth of authigenic magnetic minerals, which was probably triggered by another process. Since the ages of remagnetization and main deformation are similar, this mechanism could relate to local pressure solution and/or changing pore fluid pressure induced by tectonic stress. However, this raises the question of why did remagnetization occur during different stages of folding in northern and southern NE Rhenish Massif.

[46] A second remagnetization predominantly carried by hematite is recorded in rocks from cores with steeply dipping bedding planes. Of Late Triassic to Early Jurassic age, this remagnetization either relates to hematite-bearing mineralizations during the uplift of the Rhenish shield, or it was caused by oxidizing fluids percolating from weathering surface in zones of enhanced permeability.

\subsection{Interpretation of the REE Patterns From Leachates}

[47] The occurrence of $\mathrm{Ba}$ and the enrichment in MREEs (Figure 8), which is most pronounced in Middle Devonian clastics, indicate that early illitization was accompanied by mineralization of Ba-rich minerals, probably barite. Thermally driven fluid flows could have mobilized $\mathrm{Ba}$ from sedimentary-exhalative deposits that were frequently described along synsedimentary fault zones in the NE Rhenish Massif (e.g., Meggen ore deposit; see Werner [1989]). The characteristic enrichment in MREEs in the leachates with high $\mathrm{Ba}$ contents is probably inherited from those synsedimentary mineral deposits. The negative correlation of MREE-enrichment and $\mathrm{Fe}_{2} \mathrm{O}_{3}$ and $\mathrm{CaO}+\mathrm{P}_{2} \mathrm{O}_{5}$ contents in leachates of samples affected by the later illitization indicates mineralization of $\mathrm{Fe}$ oxides and possibly apatite with flat REE patterns. This diagenetic event appears to be coeval to the deformation and could have caused the chemical remagnetization in the Upper Devonian and Lower Carboniferous units.

[48] The REE patterns of the leachates from different lithologies in the NE Rhenish Massif show varying occurrences of $\mathrm{Eu}$ (and $\mathrm{Ce}$ ) anomalies. This indicates varying oxidation-reduction conditions during mineralization of soluble mineral phases such as barite, Fe oxides and apatite. A pervasive migration of fluids on a regional scale is expected to homogenize the REE signatures of soluble minerals. The observation of two mineralization events of different ages, and the different oxidation-reduction conditions during diagenesis, are against regional fluid flows in the NE Rhenish Massif.

\section{Conclusions}

[49] The present work combines mineralogy, REE chemistry and $\mathrm{K}$-Ar isotope dating of clay minerals as well as REE chemistry of Fe oxide leachates to study remagnetized sedimentary rocks from Paleozoic outcrops in the NE Rhenish Massif. The results yield important implications for the processes and mechanisms responsible for the Late Paleozoic remagnetization of the studied area.

[50] 1. In the predominantly Late Devonian and Early Carboniferous carbonates, clay diagenesis and remagnetization are coeval at $324 \pm 3$ Ma with respect to the main phase of deformation in the Late Carboniferous ( 320-310 Ma). In Middle Devonian clastics, authigenic illite preserved an older diagenetic event at $348 \pm 7 \mathrm{Ma}$, while the age of remagnetization is not different from that of the remagnetization in the younger sequences. Formation of secondary magnetite might be linked to chemical processes associated with the smectite-to-illite transition in the Late Devonian and Early Carboniferous rocks, while a different mechanism seems to have induced the growth of magnetite in the Middle Devonian clastics.

[51] 2. Leaching experiments of the $<0.2 \mu \mathrm{m}$ clay fractions outline different REE patterns and Eu/Ce anomalies in the soluble mineral phases of the rocks, representing a strong evidence against a fluid flow on a regional scale triggered by orogenesis. The Fe oxide leachates of all 
remagnetized rocks are enriched in MREEs. The degree of MREE enrichment is generally correlated with the amount of $\mathrm{Ba}$ in the leachates, indicating a mobilization and precipitation of barite during diagenesis. This process is not necessarily connected to the remagnetization, since the REE spectra of leachates from Late Devonian and Early Carboniferous rocks indicate the precipitation of Fe oxides and apatite with flat REE spectra subsequent to barite mobilization, which is probably connected to the older diagenetic event preserved in the Middle Devonian rocks.

[52] 3. The process responsible for the remagnetization processes in the studied area is rather complex. The regional migration of orogenic-type fluids, which is thought to be responsible for widespread remagnetization in Paleozoic rocks of the Variscan realm of North America, can be excluded for the NE Rhenish Massif. Alternatively, chemical changes associated with the smectite-to-illite transition could be responsible for remagnetization of Late Devonian and Early Carboniferous rocks. This process requires a fluid phase that originated either from pore fluids or from local migration of fluids in fractures and faults. In the Middle Devonian strata of the NE Rhenish Massif, illite generation and remagnetization are not contemporaneous and oxidation of pyrite was not observed. In this case, remagnetization was obviously related to a different mechanism. It can be speculated that it was induced by pressure solution and/or changing pore fluid pressure during deformation of the Middle Devonian sequences. However, this does not agree with the spatial variation in timing of remagnetization relative to the migration of the deformation front from south to north. More work is needed to elucidate the remagnetization process in the Middle Devonian clastics from NE Rhenish Massif. The Mesozoic remagnetization is carried by hematite and is either related to hematite-bearing mineralization during uplift in the Mesozoic, or owing to oxidizing fluids percolating from weathering surface and penetrating zones of enhanced permeability.

[53] 4. Although isotopic studies of clay minerals are commonly carried out on clastic lithologies, carbonates turned out to be very well suited for the geochemical and geochronologic study of their clay material. This is of importance, since these lithologies generally yield more reliable paleomagnetic results than clastics. The use of ${ }^{40} \mathrm{Ar} /{ }^{36} \mathrm{Ar}$ versus ${ }^{40} \mathrm{~K} /{ }^{36} \mathrm{Ar}$ plots and the interpretation of $\mathrm{K}-\mathrm{Ar}$ isochrons are also of prime importance to identify either possible mixtures of illite generations with detrital material, or diffusive loss of radiogenic ${ }^{40} \mathrm{Ar}$. The Fe oxide leaching experiments are able to outline an efficient link between carriers of magnetization and geochemistry of illite and other, more soluble, minerals, becoming a powerful method to characterize the geochemical fingerprint of diagenetic events. However, contamination by detrital, REErich minerals, such as apatite or monazite can hamper the interpretation of results from leaching experiments.

[54] Acknowledgments. We would like to thank the technical staff of the Centre de Géochimie de la Surface, Strasbourg, for assistance during the course of the study: R. Wendling, T. Perrone, J. Samuel, R. Rouault, D. Million, J. L. Cézard, P. Larqué, G. Morvan, and P. Karcher. Special thanks are due to R. Wendling for his enormous amount of work on the separation of the clay size fractions. Funding of the project by a grant of the Deutsche Forschungsgemeinschaft to H. Soffel and V. Bachtadse (So72/62) is also acknowledged.

\section{References}

Ahrendt, H., N. Clauer, J. C. Hunziker, and K. Weber (1983), Migration of folding and metamorphism in the Rheinische Schiefergebirge deduced from $\mathrm{K}-\mathrm{Ar}$ and $\mathrm{Rb}-\mathrm{Sr}$ age determinations, in Intracontinental Fold Belts: Case Studies in the Variscan Belt of Europe and the Damara Belt in Namibia, edited by H. Martin and F. W. Eder, pp. 323-338, Springer, New York.

Bachtadse, V., F. Heller, and A. Kröner (1983), Palaeomagnetic investigations in the Hercynian mountain belt of central Europe, Tectonophysics, 91, 285-299, doi:10.1016/0040-1951(83)90046-X.

Belousova, E. A., W. L. Griffin, S. Y. O'Reilly, and N. I. Fisher (2002), Apatite as an indicator for mineral exploration: Trace-element compositions and their relationships to host rock type, J. Geochem. Explor., 76, 45-69, doi:10.1016/S0375-6742(02)00204-2.

Bonhomme, M. G., R. Thuizat, Y. Pinault, N. Clauer, R. Wendling, and R. Winkler (1975), Methodé de Datation Potassium-Argon: Appareillage et Technique, 53 pp., Cent. de Geochem. de la Surface, Univ. Louis Pasteur, Strasbourg, France.

Borradaile, G. J. (1994), Remagnetisation of a rock analogue during experimental triaxial deformation, Phys. Earth Planet. Inter., 83, 147-163, doi:10.1016/0031-9201(94)90069-8.

Brindley, G. W., and G. Brown (1980), Crystal Structures of Clay Minerals and Their X-Ray Identification, Mineral. Soc., London.

Brooks, C., S. R. Hart, and T. Wendt (1972), Realistic use of two-error regression treatments as applied to rubidium-strontium data, Rev. Geophys., 10, 551-577, doi:10.1029/RG010i002p00551.

Brothers, L. A., M. H. Engel, and R. D. Elmore (1996), The late diagenetic conversion of pyrite to magnetite by organically complexed ferric iron, Chem. Geol., 130, 1-14, doi:10.1016/0009-2541(96)00007-1.

Clauer, N. (2006), Towards an isotopic modeling of the illitization process based on data of illite-type fundamental particles from mixed layered illite-smectite, Clays Clay Miner., 54, 116-127, doi:10.1346/ CCMN.2006.0540113.

Clauer, N., and S. Chaudhuri (1995), Clays in Crustal Environments, Isotope Dating and Tracing, 359 pp., Springer, New York.

Clauer, N., and S. Chaudhuri (1999), Isotopic dating of very-low grade metasedimentary and metavolcanic rocks: Techniques and methods, in Low-Grade Metamorphism, edited by M. Frey and D. Robinson, pp. 202-226, Blackwell Sci., Malden, Mass.

Clauer, N., J. Srodon, J. Francu, and V. Sucha (1997), K-Ar dating of illite fundamental particles separated from illite/smectite, Clay Miner., 32, 181-196, doi:10.1180/claymin.1997.032.2.02.

Cox, A., and G. B. Dalrymple (1967), Statistical analysis of geomagnetic reversal data and the precision of potassium-argon dating, J. Geophys. Res., 72, 2603-2614, doi:10.1029/JZ072i010p02603.

Cullers, R. L., S. Chaudhuri, N. Kilbane, and R. Koch (1979), Rare-earths in size fractions and sedimentary rocks of Pennsylvanian-Permian age from mid-continent of the U.S.A., Geochim. Cosmochim. Acta, 43, 1285-1301, doi:10.1016/0016-7037(79)90119-4.

Dunlop, D. J., and Ö. Özdemir (1997), Rock Magnetism: Fundamentals and Frontiers, 573 pp., Cambridge Univ. Press, New York.

Dunoyer de Segonzac, G. (1969), Les Minéraux Argileux dans la Diagenèse: Passage au Métamorphisme, 317 pp., Serv. de la Carte Géol. d'Alsace-Lorraine Mém., Strasbourg, France.

Elliott, W. C., A. Basu, J. M. Wampler, R. D. Elmore, and G. H. Grathoff (2006), Comparison of K-Ar ages of diagenetic illite-smectite to the age of a chemical remanent magnetization (CRM): An example from the Isle of Skye, Scotland, Clays Clay Miner., 54, 314-323, doi:10.1346/ CCMN.2006.0540303.

Elmore, R. D., J. Kelley, M. Evans, and M. T. Lewchuk (2001), Remagnetization and orogenic fluids: Testing the hypothesis in the central Appalachians, Geophys. J. Int., 144, 568-576, doi:10.1111/j.1365-246X.2001.00349.x.

Epstein, A. G., J. B. Epstein, and L. D. Harris (1977), Conodont color alteration-An index to organic metamorphism, Geol. Surv. Prof. Pap. 995, 31 pp., U.S. Gov. Print. Off., Washington, D.C.

Folk, R. L. (1959), Practical petrographic classification of limestones, Am. Assoc. Pet. Geol. Bull., 43, 1-38.

Franke, W. (2000), The mid-European segment of the Variscides: Tectonostratigraphic units, terrane boundaries and plate tectonic evolution, in Orogenic Processes: Quantification and Modelling in the Variscan Belt, edited by W. Franke et al., pp. 35-61, Geol. Soc., London.

Gill, J. D., D. R. Elmore, and M. H. Engel (2002), Chemical remagnetization and clay diagenesis: Testing the hypothesis in the Cretaceous sedimentary rocks of northwestern Montana, Phys. Chem. Earth, 27, $1131-1139$.

Govindaraju, K. (1994), Compilation of working values and sample description for 383 geostandards, Geostand. Newsl., 18, 1-158.

Govindaraju, K., and I. Roelandst (1993), Second report (1993) on the first three GIT-IWG rock reference samples: Anorthosite from Greenland, AN-G; basalte d'Essay-la-Cote, Be-N; granite de Beauvoir, MA-N, Geostand. Newsl., 17, 227-294, doi:10.1111/j.1751-908X.1993.tb00142.x. 
Hirt, A. M., A. Banin, and A. U. Gehring (1993), Thermal generation of ferromagnetic minerals from iron-enriched smectites, Geophys. J. Int. 115, 1161-1168, doi:10.1111/j.1365-246X.1993.tb01518.x.

Honty, M., N. Clauer, and V. Sucha (2008), Rare-earth elemental systematics of mixed-layered illite-smectite from sedimentary and hydrothermal environments of the western Carpathians (Slovakia), Chem. Geol., 249 167-190, doi:10.1016/j.chemgeo.2007.12.009.

Hudson, M. R., R. L. Reynolds, and N. S. Fishman (1989), Synfolding magnetization in the Jurassic Preuss Sandstone, Wyoming-Idaho-Utah thrust belt, J. Geophys. Res., 94, 13,681-13,705, doi:10.1029/ JB094iB10p13681.

Jackson, M., C. McCabe, M. M. Ballard, and R. Van der Voo (1988), Magnetite authigenesis and diagenetic paleotemperatures across the northern Appalachian Basin, Geology, 16(7), 592-595, doi:10.1130/ 0091-7613(1988)016<0592:MAADPA > 2.3.CO;2

Katz, B., D. R. Elmore, M. Cogoini, M. H. Engel, and S. Ferry (2000), Associations between burial diagenesis of smectite, chemical remagnetization, and magnetite authigenesis in the Vocontian Trough, SE France, J. Geophys. Res., 105, 851-868, doi:10.1029/1999JB900309.

Kent, D. V. (1985), Thermoviscous remagnetization in some Appalachian limestone, Geophys. Res. Lett., 12, 805-808, doi:10.1029/ GL012i012p00805.

Kodama, K. P. (1988), Remanence rotation due to rock strain during folding and the stepwise application of the fold test, J. Geophys. Res., 93, $3357-$ 3371, doi:10.1029/JB093iB04p03357.

Königshof, P. (1992), Der Farbänderungsindex von Conodonten (CAI) in paläozoischen Gesteinen (Mitteldevon bis Unterkarbon) des Rheinischen Schiefergebirges, 118 pp., Senckenbergische Naturforsch. Ges., Frankfurt, Germany.

Kossmat, F. (1927), Gliederung des varistischen Gebirgsbaues, Abh. Sächs. Geol. Landesamt, 1, 1-39.

Kreuzer, H., and W. Harre (1975), K/Ar-Altersbestimmungen an Hornblenden und Biotiten des Kristallinen Odenwaldes, Der Aufschluâ, 27, 71-77.

Kübler, B. (1966), La cristallinité de l'illite et les zones tout à fait supérior du métamorphisme, in Colloque sur les Etage Tectoniques, pp. 105-122, Neuchatel, Switzerland.

Larqué, P., and F. Weber (1978), Sequences sedimentaires et lithostratigraphie de la serie paleogene du Velay: Sedimentary sequences and lithostratigraphy of the Paleogene series of Velay, Sci. Geol. Bull., $31(4), 151-155$.

Lee, D. E., and H. Bastron (1967), Fractionation of rare-earth elements in allanite and monazite as related to geology of the Mt. Wheeler mine area, Nevada, Geochim. Cosmochim. Acta, 31, 339-356, doi:10.1016/00167037(67)90046-4.

Liewig, N., N. Clauer, and F. Sommer (1987), Rb-Sr and K-Ar dating of clay diagenesis in Jurassic sandstone reservoirs, North Sea, Am. Assoc. Pet. Geol. Bull., 71, 1467-1474.

Lu, G., S. Marshak, and D. V. Kent (1990), Characteristics of magnetite carriers responsible for Late Paleozoic remagnetizations in carbonate strata of the mid-continent, U.S.A., Earth Planet. Sci. Lett., 99, $351-$ 361, doi:10.1016/0012-821X(90)90139-O.

Lu, G., C. McCabe, J. S. Hanor, and R. E. Ferrell (1991), A genetic link between remagnetization and potassium metasomatism in the Devonian Onondaga Formation, Northern Appalachian Basin, Geophys. Res. Lett., 18, 2047-2050, doi:10.1029/91GL02665.

Ludwig, K. (2001), Isoplot/Ex, rev. 2.49: A geochronological toolkit for Microsoft Excel, Berkeley Geochronology Cent., Berkeley, Calif.

McCabe, C., and J. E. T. Channell (1994), Late Paleozoic remagnetization in limestones of the Craven Basin (northern England) and the rock magnetic fingerprint of remagnetized sedimentary carbonates, J. Geophys. Res., 99, 4603-4612, doi:10.1029/93JB02802.

McCabe, C., R. Van der Voo, D. R. Peacor, C. R. Scotese, and R. Freeman (1983), Diagenetic magnetite carries ancient yet secondary remanence in some Palaeozoic sedimentary carbonates, Geology, 11, 221-223, doi:10.1130/0091-7613(1983)11<221:DMCAYS>2.0.CO;2.

McLennan, S. M. (1989), Rare earth elements in sedimentary rocks: Influence of provenance and sedimentary processes, in Geochemistry and Mineralogy of Rare Earth Elements, edited by B. R. Lipin and G. A. McKay, pp. 170-200, Mineral. Soc. of Am., Chantilly, Va.

Mehra, O. P., and M. L. Jackson (1960), Iron oxide removal from soils and clays by a dithionite-citrate system buffered with sodium bicarbonate, in Clays and Clay Minerals: Proceedings of the 7th National Conference, pp. 317-327, Pergamon, New York.

Moore, D. M., and R. C. Reynolds (1989), Identification of mixed layered minerals, in X-Ray Diffraction and the Identification and Analyses of Clay Minerals, edited by D. M. Moore and R. C. Reynolds, pp. 241269, Oxford Univ. Press, New York.

Nier, A. O. (1950), A redetermination of the relative abundances of the isotopes of carbon, nitrogen, oxygen, argon and potassium, Phys. Rev. $77,99-102$
Oliver, J. (1986), Fluids expelled tectonically from orogenic belts: Their role in hydrocarbon migration and other geologic phenomena, Geology, 14, 99-102, doi:10.1130/0091-7613(1986)14<99:FETFOB >2.0.CO;2.

Oncken, O., C. von Winterfeld, and D. Dittmar (1999), Accretion of a passive margin: The Late Paleozoic Rhenohercynian fold and thrust belt (Middle European Variscides), Tectonics, 18, 75-91, doi:10.1029/ 98TC02763

Opdyke, N. D., and J. E. T. Channell (1996), Magnetic Stratigraphy, 346 pp., Academic, London.

Paproth, E., and M. Wolf (1973), Zur paläogeographischen Deutung der Inkohlung im Devon und Karbon des nördlichen Rheinischen Schiefergebirges, Neues Jahrb. Geol. Palaeontol. Monatsh., 8, 469-493.

Plesch, A., and O. Oncken (1999), Orogenic wedge growth during collision: Constraints on mechanics of a fossil wedge from its kinematic record (Rhenohercynian FTB, central Europe), Tectonophysics, 309(1-4), 117-139, doi:10.1016/S0040-1951(99)00135-3.

Reuter, A. (1985), Korngrößenabhängigkeit von K-Ar Datierungen und Illit-Kristallinität anchizonaler Metapelite und Metatuffe aus dem Rheinischen Schiefergebirge, 91 pp., Göttinger Arb. zur Geol. und Paläontol., Georg-August-Univ., Göttingen, Germany.

Reuter, A. (1987), Implications of K-Ar ages of whole-rock and grain size fractions of metapelites and intercalated metatuffs within an anchizonal terrane, Contrib. Mineral. Petrol., 97, 105-115, doi:10.1007/BF00375218. Reuter, A., and R. D. Dallmeyer (1989), K-Ar and ${ }^{40} \mathrm{Ar} /{ }^{39} \mathrm{Ar}$ dating of cleavages formed during very low-grade metamorphism: A review, in Evolution of Metamorphic Belts: 1987 Joint Meeting of the Metamorphic Studies Group and IGCP Project 235, edited by J. S. Daly, R. A. Cliff, and B. W. D. Yardley, pp. 161-171, Geol. Soc., London.

Robion, P., and G. J. Borradaile (2001), Stress remagnetization in pyrrhotite-calcite synthetic aggregates, Geophys. J. Int., 144, 96-104, doi:10.1046/j.0956-540X.2000.01299.x.

Samuel, J., R. Rouault, and Y. Besnus (1985), Analyse multi-élémentaire standardisée des matériaux géologiques en spectrométrie d'émission par plasma à couplage inductif, Analysis, 13, 312-317.

Stamatakos, J., A. M. Hirt, and W. Lowrie (1996), The age and timing of folding in the central Appalachians from paleomagnetic results, Geol. Soc. Am. Bull., 108(7), 815-829, doi:10.1130/0016-7606(1996)108< 0815:TAATOF $>2.3 . \mathrm{CO} ; 2$

Steiger, R. H., and E. Jäger (1977), Subcommission on Geochronology: Convention on the use of decay constants in geo- and cosmochronology, Earth Planet. Sci. Lett., 36, 359-362, doi:10.1016/0012-821X (77)90060-7.

Suk, D., D. R. Peacor, and R. Van der Voo (1990), Replacement of pyrite framboids by magnetite in limestone and implications for paleomagnetism, Nature, 345, 611-613, doi:10.1038/345611a0.

Suk, D., R. Van der Voo, and D. R. Peacor (1993), Origin of magnetite responsible for remagnetization of early Paleozoic limestones of New York State, J. Geophys. Res., 98, 419-434, doi:10.1029/92JB01323.

Sun, W., and M. Jackson (1994), Scanning electron microscopy and rock magnetic studies of magnetic carriers in remagnetized early Paleozoic carbonates from Missouri, J. Geophys. Res., 99, 2935-2942, doi:10.1029/93JB02761.

Taylor, S. R., and S. M. McLennan (1985), The Continental Crust: Its Composition and Evolution, 312 pp., Blackwell, Malden, Mass.

Todt, W. A., U. Altenberger, and J. F. von Raumer (1995), U-Pb data on zircons for the thermal peak of metamorphism in the Variscan Odenwald, Germany, Geol. Rundsch., 84(3), 466-472, doi:10.1007/s005310050018.

Tohver, E., A. B. Weil, J. G. Solum, and C. M. Hall (2008), Direct dating of carbonate remagnetization by ${ }^{40} \mathrm{Ar} /{ }^{39} \mathrm{Ar}$ analysis of the smectite-illite transformation, Earth Planet. Sci. Lett., 274, 524-530, doi:10.1016/ j.eps1.2008.08.002.

Van der Voo, R. (1990), Phanerozoic paleomagnetic poles from Europe and North America and comparisons with continental reconstructions, Rev. Geophys., 28, 167-206, doi:10.1029/RG028i002p00167.

Walliser, O. H. (1981), The geosynclinal development of the Rheinische Schiefergebirge (Rhenohercynian zone of the Variscides, Germany), Geol. Mijnbouw, 60, 89-96.

Werner, W. (1989), Contribution to the genesis of the sedex-type mineralizations of the Rhenish Massif (Germany): Implications for future $\mathrm{Pb}$ Zn exploration, Geol. Rundsch., 78(2), 571-598, doi:10.1007/ BF01776192.

Wilken, C. H. S. (1995), Paläo- und gesteinmagnetische Untersuchungen an paläozoischen Gesteinen aus dem Rheinischen Schiefergebirge, diploma thesis, Ludwig-Maximilians-Univ., Munich.

Woods, S. D., R. D. Elmore, and M. H. Engel (2002), Paleomagnetic dating of the smectite-to-illite conversion: Testing the hypothesis in Jurassic sedimentary rocks, Skye, Scotland, J. Geophys. Res., 107(B5), 2091, doi:10.1029/2000JB000053.

Xu, W., R. Van der Voo, and D. R. Peacor (1994), Are magnetite spherules capable of carrying stable magnetizations?, Geophys. Res. Lett., 21, $517-$ 520, doi:10.1029/94GL00366. 
York, D. (1969), Least-squares fitting of a straight line, Can. J. Phys., 46, $1845-1847$.

Zegers, T. E., M. J. Dekkers, and S. Bailly (2003), Late Carboniferous to Permian remagnetization of Devonian limestones in the Ardennes: Role of temperature, fluids, and deformation, J. Geophys. Res., 108(B7), 2357, doi:10.1029/2002JB002213.

Zwing, A., V. Bachtadse, and H. C. Soffel (2002), Late Carboniferous remagnetisation of Palaeozoic rocks in the NE Rhenish Massif, Germany, Phys. Chem. Earth, 27, 1179-1188.
Zwing, A., J. Matzka, V. Bachtadse, and H. C. Soffel (2005), Rock magnetic properties of remagnetized Palaeozoic clastic and carbonate rocks from the NE Rhenish massif, Germany, Geophys. J. Int., 160, 477-486, doi:10.1111/j.1365-246X.2004.02493.x.

V. Bachtadse, Department of Earth and Environmental Sciences, LudwigMaximilians-Universität, Theresienstrasse 41, D-80333 Munich, Germany.

N. Clauer, Centre de Géochimie de la Surface, Université Louis Pasteur, CNRS, 1 rue Blessig, F-67084 Strasbourg, France.

N. Liewig, Département Ecologie, Physiologie et Ethologie, Institut Pluridisciplinaire Hubert Curien, Université Louis Pasteur, CNRS, 23 rue Becquerel, F-67087 Strasbourg, France.

A. Zwing, Ludwig-Maximilians-Universität, Geschwister-Scholl-Platz 1, D-80539 Munich, Germany. (azwing@lmu.de) 